\title{
SEMANTICS AND SYNTAX IN OLD ENGLISH MOOD SELECTION ${ }^{1}$
}

\section{HoWARD JONES AND MORgAN MACLEOD}

(Transactions of the Philological Society, forthcoming; accepted 16 March 2020)

\section{ABSTRACT}

A principled model of mood selection in Old English (OE) has long proved elusive. We analyse the distribution of the indicative and subjunctive in the OE Bede in light of the Latin original, the syntactic construction, and a semantic model of modality which classifies clauses according to whether the situation is represented as holding in the actual or in a possible world. The choice of mood in the Latin and OE Bede differs enough to rule out slavish imitation. In certain clauses, such as result and purpose clauses, the construction type, modality, and grammatical mood all match; however, in other clauses, such as concessives, the OE subjunctive is systematically used whether the situation is represented as actual or possible. Where the grammatical mood of OE forms is ambiguous, modal verbs are often seemingly used as a substitute for the subjunctive. Our results show that while the choice of mood in the OE Bede largely correlates with the syntactic construction, the subjunctive is close to being semantically redundant. This growing redundancy may have been one of the factors in the diminishing role of inflectional mood in the later history of English.

\section{INTRODUCTION}

Despite the wealth of descriptive material available, no comprehensive semantic account exists of the factors governing mood selection in Old English. Mitchell (1985: I, 370) refrains from attempting to identify semantic properties unifying different uses of the subjunctive; more recently, Ringe \& Taylor (2014: 484) merely note the widespread occurrence of subjunctive complement clauses in Old English, without more specific discussion of when these might be selected in contrast to indicative clauses. However, the lack of such an account is not peculiar to Old English; it reflects the absence of a widely accepted semantic analysis of mood phenomena in general.

The categories of mood expressed morphologically in Old English are the indicative, imperative, and subjunctive. The imperative has a number of distinctive syntactic and semantic properties that set it off from other moods (e.g. Portner 2018: 199-200), and lies outside the scope of our paper. Of the remaining two moods, the indicative may be described as the default, semantically unmarked category (e.g. Portner 1997: 182), although even this is not universally agreed (see Portner 2018: 70). The subjunctive has proved far more resistant to characterization (for review see Nordström 2010). Among the approaches proposed are that the subjunctive marks the speaker's intent

\footnotetext{
${ }^{1}$ The authors would like to express their thanks for the comments and suggestions from Wolfgang de Melo and the anonymous referees, as well as to the audience at FGLS 20 (Bristol, January 2020) where this work was presented.
} 
not to assert the truth of a proposition (e.g. Palmer 2001), and that the subjunctive selects a specific ordering source for possible worlds according to which to evaluate a proposition; a variety of formalizations have been proposed for approaches of the latter sort (for review see Portner 2018: 78-114). The difficulty of formulating a semantic analysis of the subjunctive is complicated by the general tendency towards a more restricted use of the subjunctive in a number of Indo-European languages throughout their recorded history; it will be seen that this tendency has brought about substantial changes in the communicative function performed by mood.

Old English is in many ways an ideal subject for the investigation of verbal mood and its changing roles. As will be seen below, diachronic change of the sort exemplified by the evolution of Latin towards the Romance languages generally involved an increasing loss of freedom in the use of mood. Inflectional mood in Old English thus occupies an intermediate position between the highly restricted system observable in a modern language such as French and the greater degree of freedom that existed at earlier stages. Moreover, although Old English retains many morphological distinctions of mood, a growing degree of syncretism is apparent, and it is possible to observe the pressures that this may put on existing structures. Compared to many other early Germanic languages, Old English has a substantial body of surviving texts, most of which are available in tagged and parsed electronic corpora. As the basis for our investigation of the Old English mood system, we have chosen to focus on a single text, the Old English translation of Bede's Ecclesiastical History. This avoids the risks of trying to interpret multiple texts, produced by speakers whose linguistic backgrounds may differ, in terms of the output of a coherent, homogeneous grammatical system; the potential for such conflation is especially great in the case of Old English, given the difficulty of identifying correlations between observable variation within the surviving corpus of texts and specific sociolinguistic variables such as region or register (see Hogg 1988). Bede provides one of the most suitable sources for an in-depth study, as it provides a record of the language at the earliest stage for which substantial quantities of data are available. The original Latin version of the text was dated by Bede himself (e.g. V.23) to the year 731 (see also Plummer 1896: $x$-xlvi). The Old English translation probably dates from the following century; although the traditional attribution of the text to King Alfred is now seldom accepted (see Whitelock 1962), the language of the text is compatible with the period of his reign, at the end of the ninth century (Miller 1890). The earliest surviving manuscript, MS T, is generally dated to the first half of the tenth century (e.g. Whitelock 1962: 81), and thus provides almost a contemporary record of the Old English text. Moreover, while the text seems to have been largely the work of a single translator (Miller 1890; Whitelock 1962), it comprises a variety of styles, including historical narrative, factual exposition, and dialogue, within a substantial text of more than 70,000 words in length. As will be seen below, the existence of a Latin original provides some guidance to the translator's intentions which is independent of the form of the Old English text. 
To provide a starting point for discussion of diachronic tendencies in the role of mood, Latin may be used to exemplify the use of the subjunctive in older IndoEuropean languages. ${ }^{2}$ In Latin, the subjunctive could be used freely in main clauses, and there were many minimal pairs distinguished by mood alone (examples after Allen et al. 1903).

1. a. Imus go.1PL.IND

'We are going'

b. Eamus

go.1PL.SBJV

'Let's go'

2. a. Beati $\underline{\text { estis }}$

blessed.NOM.PL be.2PL.IND

'You are blessed'

b. Beati sitis

blessed.NOM.PL be.2PL.SBJV

'May you be blessed'

3. a. Si monebo, $\underline{\text { audiet }}$

if warn.1sG.FUT.IND hear.3sG.FUT.IND

'If I warn, he will hear'

b. Si moneam, $\underline{\text { audiat }}$

if warn.1sG.SBJV hear.3SG.SBJV

'If I were to warn, he would hear'

However, already in Latin there is a growing rigidity in the selection of mood (see Appendix 2). For example, the sequence-of-tense rules once restricted to indicative constructions were also extended to the subjunctive (Clackson \& Horrocks 2007: 58), while the restricted use of potential subjunctives in Latin (e.g. Allen et al. 1903) contrasts with the broader range of potential optatives still visible in Homeric Greek (see Goodwin 1889: 77). In many contexts, a change of mood also requires the assumption of a different syntactic structure, and even when the change does not lead to ungrammaticality the resulting sentence may still be of marginal acceptability, in the sense of not being the most felicitous or unmarked expression of a given meaning.

\footnotetext{
${ }^{2}$ In a still earlier system, seen in languages such as Ancient Greek and Sanskrit, the indicative was opposed to two other moods, the subjunctive and the optative, with the latter expressing in general a greater degree of unreality. Synchronically (and cross-linguistically) the morphological distinction between subjunctive and optative showed many parallels to that between present and past tenses, and the two moods have sometimes been viewed as essentially present and past 'subjunctives' (see Palmer 2001: 204-7). However, it has also been suggested that the IE subjunctive originally had a temporal meaning, such as futurity, and that its modal uses were relatively late (see Willmott 2007). The moods termed 'subjunctive' in Latin and the Germanic languages descend in fact from the IE optative, and the following discussion should be understood as applying principally to the IE optative and its reflexes, without commitment as to whether it also extends to the IE subjunctive.
} 
4. a. Ex culpa primi hominis factum est, out fault.ABL first.GEN person.GEN do.PRF.PPL.NOM be.3SG.IND ut esuriamus

that hunger.1PL.SBJV

'From the fault of the first man it has come to pass that we hunger' (I.27)

b. ??Ex culpa primi hominis factum est, out fault.ABL first.GEN person.GEN do.PRF.PPL.NOM be.3SG.IND ut esurimus

that hunger.1PL.IND

'From the fault of the first man it has come to pass, in the same way that we hunger'

This rigidity has increased during the evolution of the Romance languages from Latin, towards the typical modern pattern that can be seen in a language such as French. Here subjunctives are largely restricted to subordinate clauses, and the mood is determined mainly by the type of construction, through factors such as the choice of matrix verb.

5. J'espère que c'est vrai $\mathrm{I}=$ hope.1SG that it=be.3SG.IND true 'I hope that it's true'

6. Je veux que ce soit vrai I want.1SG that it be.3SG.SBJV true 'I want it to be true'

Moreover, the role of mood in signalling counterfacuality has been supplanted in some constructions by tense alone (see further Iatridou 2000).

7. Si je l'avertissais, il m'entendrait

if I him=warn.1SG.IMPF.IND he me=hear.3sG.COND

'If I warned him, he would hear me'

Despite this increasing rigidity, however, some semantically motivated minimal pairs continue to exist.

8. a. Je cherche quelqu'un qui peut m'aider I seek.1SG someone who can.3SG.IND me=help.INF 'I'm looking for someone who can help me' (there is such a person, and I'm looking for him/her)

b. Je cherche quelqu'un qui puisse m'aider I seek.1SG someone who can.3SG.SBJV me=help.INF 'I'm looking for someone who can help me' (anyone, whoever it might be) 
The progressive marginalization of the subjunctive has made it difficult for any semantic theory to encompass the full range of data. Most research has tended to focus on the selection relationships between matrix verbs and their complements, resulting in models that have difficulty addressing many uses of the subjunctive found in older languages, both independently and in clauses other than complement clauses; conversely, models that do address such constructions often appeal to very general distinctions such as realis/irrealis, and have greater difficulty addressing fine-grained differences in selection properties (for review see Portner 2018: 70-114). Our goal, however, is to propose an approach to mood that can address the full range of observed phenomena.

\section{SEMANTIC MODEL}

Our objective is to identify patterns in the use of indicative and subjunctive forms in the OE Bede in order to shed light on the functions of these moods. We do so by analysing the extent to which the choice of grammatical mood correlates with other variables, in particular:

- The modality of the sentence;

- The type of clause in which the verb form occurs;

- The grammatical mood of the Latin original.

\subsection{MODALITY}

By 'modality' we refer to the way in which a speaker (who, in the OE Bede, may be the narrator) situates the content of a proposition by reference to actual world or possible worlds. In possible world semantics, the actual world of the speaker is viewed as one of a number of worlds which could obtain or could have obtained (see Menzel 2017, Portner 2018). Thus, in He's coming, the proposition is represented as obtaining in the actual world of the speaker. But in I doubt he's coming, the complement clause he's coming is represented as an event in a possible world, here a world which the speaker doubts will come about, rather than in the actual world of the speaker. In Helen thought she saw the Queen, the speaker represents she saw the Queen as an event in the world of Helen's thoughts. And in John pretended he was elsewhere, the speaker represents he was elsewhere as a situation in the world of John's imagination. As these examples show, the nature of the possible world may vary from sentence to sentence: here from doubt, to thought, to pretence. It is also noteworthy that some worlds, while possible in the context in which they are evoked, exclude the actual world of the speaker; this is true of John pretended he was elsewhere. 
In order to model the clause types found in the OE Bede (and the Latin original) ${ }^{3}$ we use three categories of modality, as follows:

\begin{tabular}{|l|c|}
\hline \multicolumn{1}{|c|}{ Category of modality } & Symbol \\
\hline The actual world & $\mathrm{w}$ \\
\hline $\begin{array}{l}\text { Some possible world, which } \\
\text { may be the actual world }\end{array}$ & $\exists \mathrm{w}$ \\
\hline $\begin{array}{l}\text { Some possible world other } \\
\text { than the actual world }\end{array}$ & $\neq \mathrm{w}$ \\
\hline
\end{tabular}

Table 1: Categories of Modality

Our three categories of ' $w$ ', ' $\exists w$ ', and ' $\neq w$ ' correspond to some extent with the categories 'realis', 'potential', and 'irrealis', respectively, which occur in the literature. ${ }^{4} \mathrm{We}$ avoid the latter terms for two reasons. First, they are sometimes used for grammatical, rather than semantic, categories; accordingly, the indicative would be called the 'realis' mood..$^{5}$ In our analysis, however, we wish to make clear the strict separation between semantic and grammatical categories. Secondly, the label 'potential' may suggest prospective possibility, whereas ' $\exists w$ ' has a wider semantic range, and also includes cases, such as Helen thought she saw the Queen, in which the possible world evoked is not prospective.

Categories of modality and grammatical moods often correspond, with the indicative used for ' $w$ ' propositions and the subjunctive for ' $\exists w$ ' or ' $\neq w$ ' propositions. But the overlap is rarely perfect, and there is considerable cross-linguistic variation. For example, the phrase 'it is impossible that' introduces a ' $\neq \mathrm{w}$ ' proposition in our model, but, while modern French uses the subjunctive, e.g. Il est impossible qu'il vienne, Present-Day German uses the indicative: Es ist unmöglich, dass er kommt.

Distinctions of modality can be more fine-grained than between the three categories in our model; see Palmer (2001) or Portner (2018) for examples of more elaborate subdivisions. However, many of these subdivisions correlate with clause type. For example, the subdivision of modality (i.e. the nature of the possible world) represented in a purpose clause is 'purposive', while the subdivision represented in a complement clause after a verb of doubting is 'speculative' (see these categories in Palmer 2001: 22). As we are testing for the semantic function or contribution of the

\footnotetext{
${ }^{3}$ Our semantic model is intended to be applicable cross-linguistically.

${ }^{4}$ See Palmer (2001: 1-2, 8). These three labels are used particularly in studies of conditional clauses, e.g. Trost (1939) for Latin (who uses 'potentialis' instead of 'potential'); they also correspond roughly to Mitchell's categories for Old English of conceded/denied, open, and rejected (1985: II, 770-3).

5 See Palmer (2001: 2). Conversely, in philosophical treatments, 'indicative' and 'subjunctive' are sometimes used as semantic categories of modality rather than as grammatical terms (e.g. Edgington 2014).
} 
Old English moods as generally as possible, we avoid modal subdivisions which are, at least in part, a function of the type of clause in which those moods are used. ${ }^{6}$

We now review each of the principal clause types found in the OE Bede and distinguish between those which refer to the actual 'w' world and those which include at least some reference to worlds defined as ' $\exists w$ ' or ' $\neq w$ '. We use Present-Day English (PDE) to illustrate these clause types. In this account we do not discuss differences in the time reference of a clause except when the modality of a clause is itself affected by such differences. Further details and a more formal account are given in Appendix 1.

\subsubsection{MAIN CLAUSES ${ }^{7}$}

These may be divided between actual-world ('w') and possible-world (' $\exists w$ ') main clauses. The former, of the type she came, she is coming, she will come, represent situations as obtaining in the actual world of the speaker. This is so even if the time reference is future, so long as the speaker represents the situation as such - it is the speaker's actual world, rather than ours, which matters. Possible-world main clauses represent situations in various types of possible worlds, e.g. she should come (obligation, a type of 'deontic' modality) or she might come (potentiality, a type of 'epistemic' modality). Using the notation in the table above, we place the clauses in parentheses and label these parentheses as follows:

9. (She came/is coming/will come $)^{\mathrm{w}}$

10. (She should come) $\exists^{\mathrm{w}}$

11. (She might come) $\exists^{\mathrm{w}}$.

\subsubsection{SUBORDINATE CLAUSES}

\subsubsection{TEMPORAL CLAUSES}

These denote situations preceding, following, or overlapping in time with that of the main clause. The situations in both the main and subordinate clauses may be represented as obtaining in the actual world of the speaker, as in the following examples:

12. He came home (before she started worrying) ${ }^{\mathrm{w}}$

\footnotetext{
${ }^{6}$ The reader may ask why, since we are dealing with only two grammatical moods, we use three categories of modality rather than two. The reason is that, in the empirical analysis, we keep an open mind as to how the categories of modality and the choice of grammatical mood relate to one another. In fact, as we shall find, the two sets of categories do not match up neatly.

${ }^{7}$ Imperative main clauses lie outside our discussion. Very few of the main clauses in our data set are interrogative.
} 
13. She was waiting (until he came) ${ }^{\mathrm{w}}$

14. She felt ill (after she ate ice-cream) ${ }^{\mathrm{w}}$

15. She was happy (when/while she was with him) ${ }^{\mathrm{w}}$

However, when the subordinate clause refers to a time following that of the main clause, the situation in the subordinate clause may be interpreted as obtaining in a possible world, rather than in the actual world of the speaker, as in:

16. He came home (before she started worrying) ${ }^{\neq \mathrm{w}}$

17. She was waiting (until he came) $)^{\exists \mathrm{w}}$

The difference between an actual-world ('w') and a possible-world (' $\exists \mathrm{w}$ ') interpretation of the clause until he came is as follows. In the ' $\mathrm{w}$ ' interpretation, the speaker represents not only she was waiting, but also that he came as obtaining in the actual world. In the ' $\exists \mathrm{w}$ ' interpretation the speaker represents she was waiting as obtaining in the actual world, but represents he came only as occurring in a possible world, in this case the world that 'she' was waiting for. In the ' $w$ ' interpretation of before she started worrying the speaker represents she started worrying as obtaining in the actual world, while in the ' $\neq \mathrm{w}$ ' interpretation the speaker represents she started worrying as obtaining, not in the actual world, but in the world which would have obtained if 'he' had not come home when he did; since 'he' did come home, that possible world excludes the speaker's actual world.

\subsubsection{CAUSAL AND RESULT CLAUSES}

Causal clauses represent situations in which cause and result normally obtain in the actual world of the speaker, with the cause being contained in the subordinate clause and the result in the main clause:

18. The baby woke up (because Mary made a noise) ${ }^{\mathrm{w}}$

Result clauses, also called 'consecutive clauses', likewise represent situations in which both cause and result normally obtain in the actual world of the speaker, but here the cause is contained in the main clause and the result in the subordinate clause:

19. Mary made a noise (so that the baby woke up) ${ }^{\mathrm{w}}$ 


\subsubsection{PURPOSE CLAUSES}

Also called 'final clauses', these can be modelled similarly to result clauses, except that the result is in the world of the intention of a participant in the narrative rather than in the actual world of the speaker. In PDE, purpose clauses may be formally identical to result clauses, although they may also be disambiguated with a modal verb such as may/might, as in the following:

20. Mary made a noise (so that the baby woke up/would wake up) ${ }^{\exists \mathrm{w}}$

\subsubsection{CONCESSIVE CLAUSES}

These describe circumstances opposing, but not preventing, the situation in the main clause. Either the circumstances are represented as obtaining in the actual world of the speaker or they are represented as possible circumstances which would not prevent the situation occurring if they did obtain. Here are examples of each type, respectively:

21. (Although Mary made a noise) ${ }^{\mathrm{w}}$, the baby did not wake up

22. (Although Mary might have made a noise) $)^{\exists \mathrm{w}}$, the baby did not wake up ${ }^{8}$

\subsubsection{COMPLEMENT CLAUSES}

These are clauses introduced by a complementizer such as 'that' or 'whether'. In some cases their modality is determined by the semantics of the verb in the main clause on which they depend. Thus, verbs (or verb phrases) such as to know, to regret, to be the case (that) introduce complement clauses in which the situation is represented as obtaining in the actual world of the speaker, as we can see by the unacceptability of such sentences as \#she knew/she regretted/it was the case that the prisoner had escaped, but the prisoner had not escaped. Conversely, some mainclause verbs introduce complement clauses in which the situation is represented as obtaining in a world which excludes the actual world of the speaker, e.g. to pretend, to lie, to be false that, as we can see in the unacceptability of such sentences as \#she pretended/she lied/it was false that the prisoner had escaped, but the prisoner had escaped. A further category of verbs introduces complement clauses in which the situation is represented as possible, e.g. to say, to command, to want, to be possible. Here the semantics of the main-clause verb neither demands nor excludes that the situation represented in the complement clause obtains in the actual world of the speaker. Thus, she said that the prisoner had escaped can be followed equally by and the prisoner had/had not escaped, and she commanded that the soldiers surrender can

\footnotetext{
${ }^{8}$ This could also be rendered as '(Even if Mary made a noise) ${ }^{\exists w}$, the baby did not wake up'.
} 
be followed equally by and they did/did not surrender. Clauses introduced by 'whether' typically introduce clauses in which the situation is represented in a possible world which could include the actual world, as in I asked her whether the prisoner had escaped - this is equally compatible with the prisoner having escaped or not in the actual world of the speaker. Using the notation in the table above, we can represent the various types of complement clause as follows:

23. She knew (that the prisoner had escaped) ${ }^{\mathrm{w}}$

24. She pretended (that the prisoner had escaped) ${ }^{\neq \mathrm{w}}$

25. She said (that the prisoner had escaped) ${ }^{\exists \mathrm{w}}$

\subsubsection{CONDITIONAL SENTENCES}

A conditional clause specifies the condition to be met for the situation in the main clause to hold; the part of a conditional sentence in which the condition is specified is 'protasis' and the part in which the contingent situation is set out is the 'apodosis'. We refer in our model to 'conditional sentences' as we are interested in the modality of both the protasis and the apodosis. In a conditional sentence the speaker does not assert the individual propositions in either the protasis or the apodosis; rather, it appears to be the entire conditional sentence which is either asserted or not (see Stalnaker 2014: 148-53 for a discussion of alternatives). In a conditional sentence which is asserted by the speaker, it is open whether the condition holds (or held) in the actual world. Thus, in If there is/was/will be smoke, there is/was/will be fire, the sentence is decidable once it is known whether there is/was smoke. By contrast, a conditional sentence may represent the condition in the protasis as not holding, as in If there were/had been smoke, there would be/would have been fire. Here the world in which the condition is met is possible in the sense that it could have held but, since the condition is not met, this world is different from the actual world. Using the notation set out above, these sentences can be written as follows:

26. (If there is/was smoke, there is/was fire) ${ }^{\mathrm{w}}$

27. (If there were/had been smoke, there would be/would have been fire) ${ }^{\neq w}$

In some languages, including PDE, a condition may be open, but the fulfilment of the condition is represented as a supposition rather than neutrally, as in If there should be/were to be smoke, there would be fire. We model these conditional sentences as representing situations obtaining in a possible world which does not rule out the actual world, as follows:

28. (If there should be/were to be smoke, there would be fire) ヨw $^{\mathrm{w}}$ 


\subsubsection{COMBINATIONS OF CLAUSES}

Clauses of the types described above may be used in combination, notably those involving complementizers. When a proposition in a complement clause depends on a main clause which includes a possible-world proposition, the dependent proposition apparently also has a possible-world interpretation. For example, in Mary might make a noise so that the baby wakes up, the clause the baby wakes up is dependent on Mary might make a noise. Although the baby wakes up would, as a result clause, have a ' $\mathrm{w}$ ' interpretation in the simple case (as outlined in 2.1.2.2), here it is represented as being contained in the world in which Mary makes a noise, that is, in a world of the type ' $\exists \mathrm{w}$ '. Another common combination involves a conditional clause after a complementizer, as in She said that, if the gate had been open, the prisoner would have escaped. This is unproblematic according to our model because the verb 'to speak' introduces a world of type ' $\exists$ w', which can be a world of any status. However, in She knew that, if the gate had been open, the prisoner would have escaped, we have a contrast between the ' $w$ ' status of simple complement clauses introduced by 'to know' and the ' $\neq w$ ' status of the conditional sentence here. In PDE, as the example shows, this is clearly acceptable, perhaps because 'to know' guarantees the validity of the conditional sentence as a whole rather than the status of the world in which the condition is valid. However, this may not be true cross-linguistically, and we comment in the empirical sections below on the choice of mood in combinations of clauses in case this shows different patterns from those in simple clause types.

\subsection{LATIN MOOD}

As part of our empirical analysis we test the correspondence between grammatical mood in Old English and Latin. If we find that the correspondence is mechanical, this could mean that the choice of mood by the translator was determined by the Latin, invalidating the translation as evidence for native Old English usage. The independence of the Old English version would be especially questionable if the distribution of moods in both languages showed a complex, but very similar, pattern. We show below that the distribution of moods in the Latin original is complex, but, as we find in the empirical analysis (Section 4.9), the distribution in the Old English translation deviates systematically from that in the Latin, suggesting that it is good evidence for native Old English usage.

Applying the semantic model set out above, we find that mood and modality do sometimes correspond in the Latin Bede, in the sense that the subjunctive is often used when the modality is ' $\exists \mathrm{w}$ ' or ' $\neq \mathrm{w}$ '. This is notably true in jussive or hortatory main clauses, such as:

\section{Adducatur aliquis aeger} bring.3SG.PRS.SBJV.PASS someone.NOM ill.NOM 'Let someone ill be brought.' (II.2) 
30. Quod utinam exin etiam nostrarum lectione which.NOM that.for hereupon yet our.GEN reading.ABL litterarum fiat letters.GEN become.3SG.PRS.SBJV

'Would that this might come to pass still further from the reading of our work.' (V.14)

In subordinate clauses we find that purpose clauses, which by definition evoke a possible world ' $\exists \mathrm{w}$ ' rather than the actual world, are systematically formed with the subjunctive in Latin, e.g.

31. ueni, $\begin{aligned} & \text { ut } \\ & \text { come.1SG.PRF that } \\ & \text { response.ACC }\end{aligned}$ lord.GEN
adferam
bring.1SG.PRS.SBJV
'I have come in order that I should bring the reply of the Lord Saviour to
Egbert' (V.9)

Among conditional clauses, those which represent situations in the actual world of the speaker are formed with the indicative, as in the following:

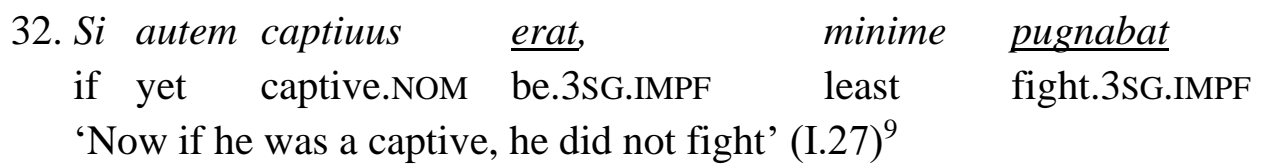

On the other hand, counterfactual conditional clauses are formed with the subjunctive: present counterfactuals with the imperfect subjunctive and past counterfactuals with the pluperfect subjunctive; here is an example of a present counterfactual:

33. si nunc in alia uita $\quad \underline{\text { essem, }}$ ibi anima
if now in other.ABL life.ABL be.1SG.IMPF.SBJV there soul.NOM
mea per intercessiones eius $\quad \underline{\text { solueretur }}$
my.NOM through intercessions.ACC his deliver.3SG.IMPF.SBJV.PASS
$a \quad$ poenis
from punishments.ABL
'If I were now in the other life, there my soul would be delivered by his
intercession from pain' (IV.20)

Elsewhere, however, the choice of mood in Latin does not correlate neatly with the categories of modality in our model. In result clauses, for example, the opposite is the case: although these represent situations in the actual world of the speaker, they are always formed with the subjunctive in Latin, e.g.

\footnotetext{
${ }^{9}$ The context of this example and (69) below is a discussion of St. Paul's remark (Romans 7.23) about being led captive into the law of sin by the law in his members. Regarding this St. Gregory says that if he had been a captive, this would mean that he had not fought, while if he had fought, he was no captive. Both conditionals are intended as expressions of logical consequence.
} 
34. Qui uidelicet mos adeo increbruit, ut which.NOM indeed custom.NOM thereto spread.3SG.PRF that paulatim ablata exinde terra fossam ad gradually remove.PRF.PPL.NOM thereafter earth.NOM hole.ACC to mensuram staturae uirilis altam reddiderit size.ACC height.GEN manly.GENhigh.ACC return.3SG.PRF.SBJV 'Indeed, this custom (of people digging out the ground where Oswald had died) spread so much that the earth, being taken away little by little, left a hole as deep as the height of a man' (III.9) ${ }^{10}$

We also find complement clauses whose contents are represented as actual by the speaker but which are routinely formed with the subjunctive, as in this example:

35. unde factum est, opitulante gratia whence do.PRF.PPL.NOM be.3SG.PRS assist.PRS.PPL.ABL grace.ABL diuina, ut multos in breui ab idolatria divine.ABL that many.ACC in short.ABL from idolatry.ABL ad fidem conuerterent Christi to faith.ACC convert.3PL.IMPF.SBJV Christ.GEN

'Thus it came about that, with the assistance of divine grace, they converted many in a short time from idolatry to the faith of Christ' (V.10)

In Latin concessive clauses there is variation in the relationship between mood and modality. In general only one mood occurs after certain conjunctions, for example the subjunctive after etiamsi and the indicative after etsi and tametsi. It should be noted that this variation shows little consistent correlation to semantic distinctions such as modality; the mood used in a given sentence is the one associated with a given conjunction, regardless as whether the speaker wishes to assert that the situation obtains in the actual world. This can be seen from the following examples, describing actual situations with the indicative and subjunctive, respectively:

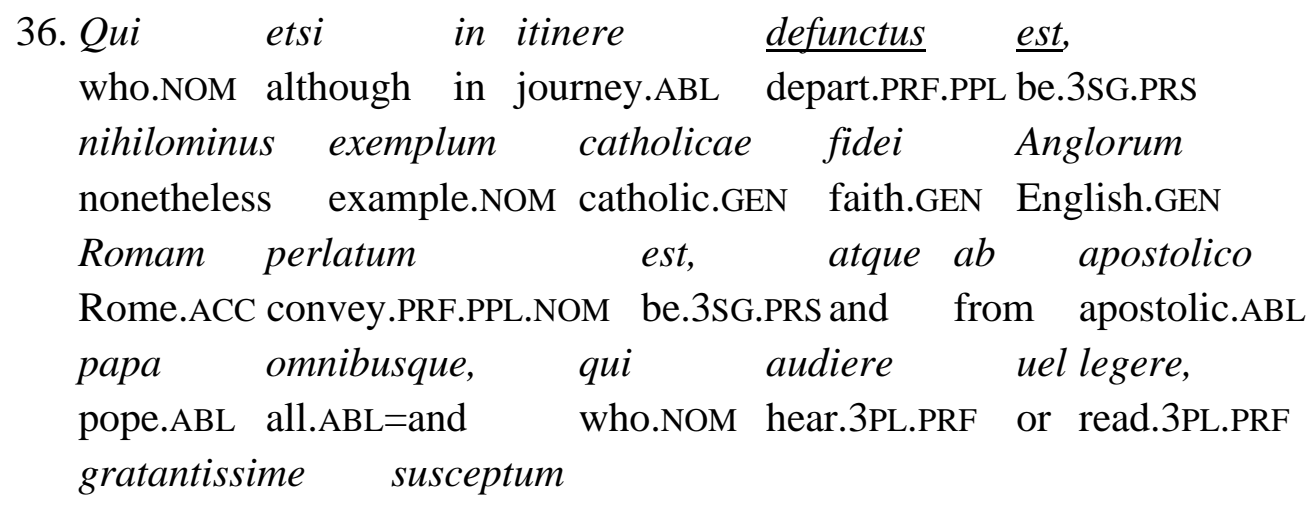

\footnotetext{
${ }^{10}$ The systematic use of the subjunctive in Latin result clauses is in striking contrast to the predominant use of the indicative in causal clauses: both clause types represent cause and result in the actual world of the speaker; see Appendix I for the semantics of these clause types and Appendix II for details of Latin causal conjunctions.
} 
agreeably.SUPL receive.PRF.PPLNOM

'Even though he died on the way, nonetheless the testimony of the catholic faith of the English was taken to Rome and most agreeably received by the apostolic pope and all those who heard or read it' (IV.16) ${ }^{11}$

37. at vero Caedualla, quamuis nomen et professionem but truly Cadwalla.NOMalthough name.ACC and profession.ACC haberet Christiani, adeo tamen erat animo have.3sG.IMPF.SBJV Christian.GEN thereto yet be.3SG.IMPF spirit.ABL ac moribus barbarus, ut ne sexui quidem muliebri, andcustoms.ABL barbarous.NOM thatnot sex.DAT even female.DAT uel innocuae paruulorum parceret aetati or innocent.DAT children.GEN spare.3SG.IMPF.SBJV age.DAT 'But in fact Cadwalla, although he had the name of, and professed himself, a Christian, was so barbarous in disposition and behaviour, that he did not even spare the female sex nor the innocent age of children' (II.20)

In temporal clauses we also find a mixed relationship between mood and modality. As shown in Appendix 2, the indicative tends to follow postquam while the subjunctive tends to follow priusquam and antequam. Although mood correlates in this way with relative position in time, it is not associated with the status of events as actual or non-actual. The subjunctive is often used to represent situations in the speaker's actual world, which the speaker asserts to have taken place; in the following two examples the indicative and subjunctive are both used to represent situations in the actual world:

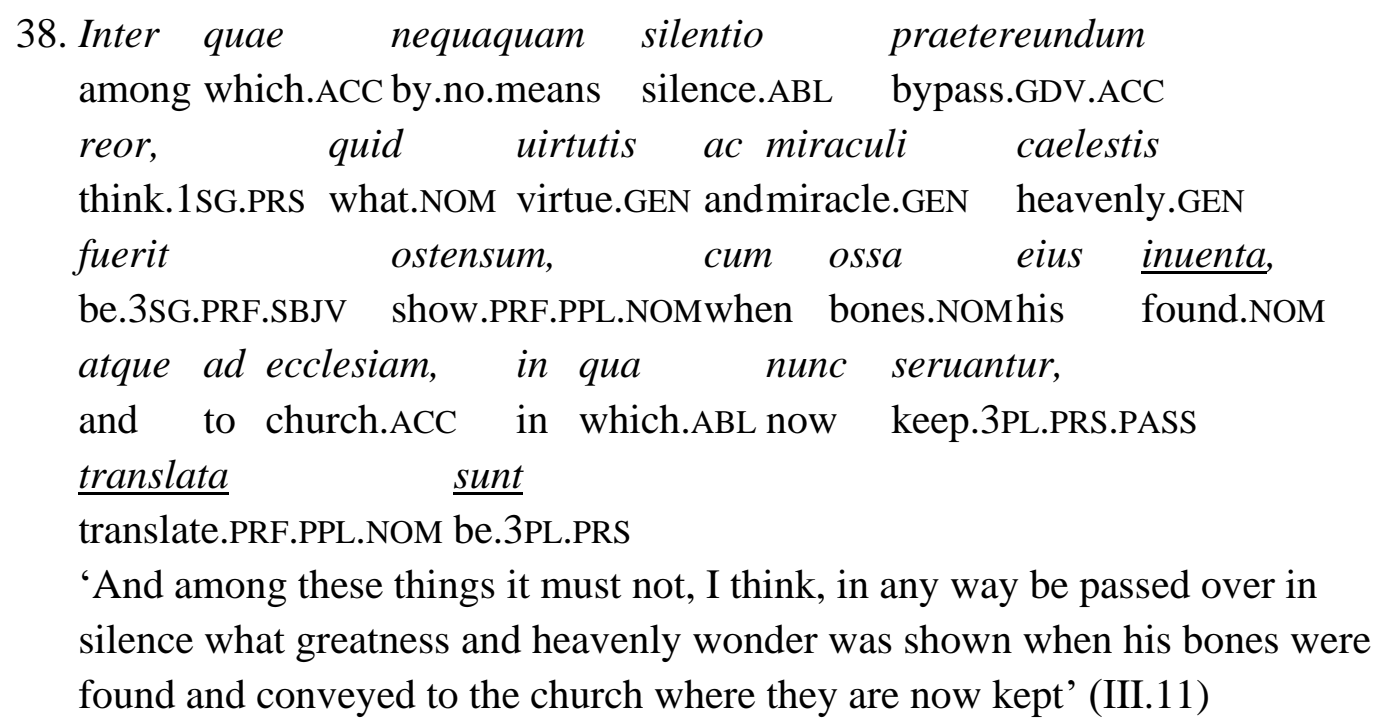

\footnotetext{
${ }^{11}$ The choice of mood in concessive clauses also correlates to some extent with tense, as illustrated by these two examples. Thus the imperfect occurs only in the subjunctive and the perfect only in the indicative. However, the present occurs in both moods.
} 
$\begin{array}{llllll}\text { 39. Qui } & \text { cum } & \text { Lugdunum } & \text { peruenissent, } & \text { Vilfrid } & a \\ \text { who.NOM } & \text { when } & \text { Lyons.ACC } & \text { reach.3PL.PPF.SBJV } & \text { Wilfrid.NOM from }\end{array}$

Dalfino ciuitatis episcopo ibi retentus

Dalfin.ABL city.GEN bishop.ABL there detain.PRF.PPL.NOM

est

be.3SG.PRS

'When they had arrived at Lyons, Wilfrid was detained there by Dalfin, the bishop of that city' (V.19)

The foregoing shows that the relationship between grammatical mood, modality, and clause type in the Latin Bede is complex. Thus, in main clauses, purpose clauses, and conditional clauses, mood and modality match in the sense that the subjunctive is reserved for non-actual (i.e. ' $\exists w$ ' or ' $\neq w$ ') situations; in result clauses and some complement clauses, there is a mismatch, with the subjunctive mood being used consistently for actual (i.e. 'w') situations; and in concessive and temporal clauses the relationship between mood and modality varies in the sense that actual (i.e. 'w') situations are sometimes represented by the indicative and sometimes by the subjunctive mood. Further details of our analysis of mood in the Latin Bede can be found in Appendix 2.

\section{MethodolOGY}

In order to understand the semantic interaction between inflectional mood and other components of the sentence, we have recorded the incidence of both indicative and subjunctive forms for selected construction types. As will be seen in Section 4.1, main clauses constitute a partial exception to this practice. To identify the relevant syntactic environments, we have used the electronic version of Bede from the YorkToronto-Helsinki Parsed Corpus of Old English Prose (Taylor et al. 2003). The text was searched using a combination of simple wildcard-based searching and the more complex morphosyntactic queries made possible through the CorpusSearch software package (Randall 2010). The search parameters used for each construction type will be described below; in general, the emphasis has been on structures that can be easily identified on formal grounds and are frequent enough to provide a meaningful quantity of data. Verb forms were categorized on the basis of morphology as indicative, subjunctive, or ambiguous. The ambiguous forms include all first-person singular non-past forms and the second person singular preterite of strong verbs, as well as the entire singular preterite of weak verbs ${ }^{12}$.

\footnotetext{
${ }^{12}$ The distinction between -est and - $e$ in the second person singular preterite of weak verbs is not maintained consistently (Mitchell 1985: I, 11).
} 
40. Ond hine bad [...] pat he him alefde \& forgefe $[. .$. and him asked that he him permitted and forgave 'And asked him to permit and grant to him...' (IV 18.308.19)

In Example (40), the weak form alefde is ambiguous, but the strong form forgefe is clearly marked as subjunctive, in contrast to the indicative forgeaf. Accordingly, the construction as a whole has been counted as subjunctive. In the preterite plural, the original distinction between indicative -on and subjunctive -en is seldom strictly preserved in surviving texts (e.g. Mitchell 1985: I, 230-232). However, these forms did not simply occur in free variation; although both types of interchange are attested, the use of -on for the subjunctive was more common than the use of -en for the indicative (e.g. Hogg 1992: 150). Accordingly, we have chosen to categorize preterite forms in -on and -an as ambiguous, but to accept forms in -en as subjunctive; during our analysis, no tendencies were observed to suggest that these forms pattern differently from other subjunctives. Plural forms in $-e$ have been treated as ambiguous (see Mitchell 1985: I, 19). As will be seen, the difference in the degree of morphological syncretism between the different tenses reduces the availability of unambiguously marked forms in certain types of construction.

\section{EMPIRICAL ANALYSIS}

\subsection{THE SUBJUNCTIVE IN MAIN CLAUSES}

The subjunctive in main clauses is relatively infrequent. Apart from its use in the apodosis of conditionals, which will be discussed separately in Section 4.7 below, only 20 examples were identified in the whole of Bede. Unlike our procedure for subordinate clauses, this number is not expressed relative to the number of corresponding indicatives; it would be misleading to compare the frequency of these constructions to the declaratives that form a large proportion of syntactically comparable indicative constructions, and the identification of indicative constructions that would form a suitable basis for comparison might involve considerable subjectivity.

Of the examples found, 15 use the subjunctive to express a command or a wish; as the same type of construction can fulfil both these functions, they might best be viewed as different contextual interpretations of the same basic deontic modality.

$\begin{array}{llll}\text { 41. Ne } & \text { forealdige } & \text { peos } & \text { hond afre. } \\ \text { not age.3SG.SBJV } & \text { this.NOM } & \text { hand.NOM ever } \\ \text { 'May this hand never grow old.' (III 4.166.8) }\end{array}$




42. Ac feor paet la sy, $\quad$ patte Godes cirice
but far that.NOM oh be.3SG.SBJV that God.GEN church.NOM
midceteacnesse
with acquisitiveness.DAT receive.3SG.SBJV
'But far be it from God's Church to acquire for gain.' (I 16.68.9)

The remaining examples, rather than expressing a desire that a situation should come to pass, present its fulfilment as in some way contingent:

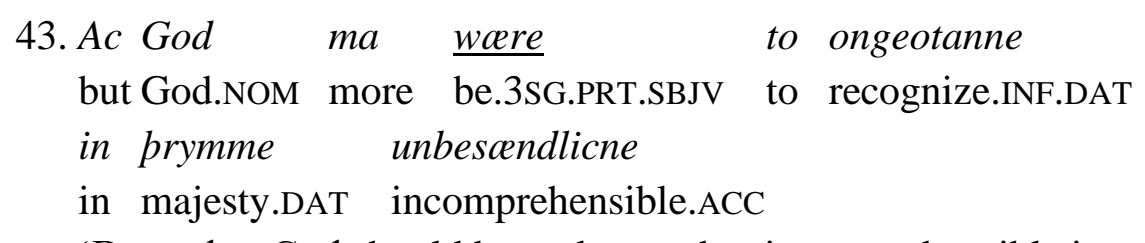

'But rather God should be understood as incomprehensible in majesty.' (III 16.224.22)

The use of the subjunctive in these constructions can be seen as comparable semantically to its use in conditionals; however, as Mitchell (1985: II, 858) suggests, such cases may not involve true syntactic ellipsis of an explicit conditional, and it may be more appropriate to interpret them as expressions of a more general epistemic potentiality. The occurrence of the subjunctive in these main-clause environments can be related with relative ease to the proposed semantic model. If a proposition is not asserted to be true, but merely stated with reference to an alternative world of evaluation (' $\exists \mathrm{w}$ ' in our semantic model), the hearer can interpret this in varying ways depending on the pragmatic context. The sentence can be seen as expressing a possibility to be fulfilled, in much the same way that infinitives, when used independently, can acquire a directive force in languages such as French (e.g. mélanger bien 'mix well'). Alternatively, the sentence can merely express a possibility to be envisioned and evaluated, and thus acquire a more general potential meaning.

Jussive subjunctives in the Old English text, such as (41) and (42), normally correspond to similar uses of the subjunctive in Latin. Example (29) above shows a Latin main-clause subjunctive which was translated into Old English in this way. Occasionally main-clause subjunctives in Old English are used to render other Latin constructions, such as imperatives, modal verbs such as debeo, or futures with deontic force. Potential subjunctives, unlike these jussive subjunctives, lack direct counterparts in the Latin text. Some, such as (43), correspond to Latin gerundive constructions; others occur in passages corresponding to Latin subordinate clauses. The semantic contribution of the subjunctive in main clauses is highly salient; if the subjunctives were merely replaced with indicatives, the sentences would become assertions of pre-existing facts. The relative infrequency of subjunctives in main clauses suggests that there was seldom need for speakers to make use of inflectional mood to express meanings such as those seen above. However, the use of main- 
clause subjunctives in Old English to translate a range of different Latin constructions suggests that, despite their infrequency, they represent a genuinely productive type.

\subsection{TEMPORAL CLAUSES}

For the purposes of analysis we have divided temporal clauses into four groups, based on the meaning of the conjunction involved: 'before' ( $a r$ and variants such as ar pon, aer pon pe, etc.), 'after' (after pon and variants), 'until' (oð paet), and 'when/while' (forms of pa, ponne, penden, and mid py); see section 2.1.2.1 for the way in which the modality of these subtypes is modelled. Only constructions of these subtypes were included in our analysis; while other constructions existed for the specification of temporal relationships, their inclusion might in some cases have proved problematic. For example, it may be questioned whether pa hwile pe 'while' was fully grammaticalized at this stage or whether hwile was still interpreted as a noun with a modifying relative clause; likewise, the temporal use of paer (literally 'where') to mean 'when' may simply have been a figurative extension of its basic spatial meaning. While the possibility must be considered that other constructions would exhibit different patterns in their use of mood, the analysis presented below will nevertheless facilitate comparison among some of the most frequent types of temporal construction in Old English. The distribution of moods in the different types of temporal clause can be seen in Table 2:

\begin{tabular}{|l|r|c|c|c|}
\hline \multirow{2}{*}{ Before } & & Indicative & Subjunctive & Ambiguous \\
\cline { 2 - 5 } & Present & - & $100 \%(3 / 3)$ & - \\
\hline \multirow{2}{*}{ After } & Past & & $55.6 \%(5 / 9)$ & $44.4 \%(4 / 9)$ \\
\cline { 2 - 5 } & Present & $100 \%(2 / 2)$ & - & - \\
\hline \multirow{2}{*}{ Until } & Past & $44.4 \%(8 / 18)$ & - & $55.6 \%(10 / 18)$ \\
\cline { 2 - 5 } & Present & - & $100 \%(2 / 2)$ & - \\
\hline \multirow{2}{*}{ When/While } & Present & $73.7 \%(14 / 19)$ & $15.8 \%(3 / 19)$ & $10.5 \%(2 / 19)$ \\
\cline { 2 - 5 } & Past & $51.9 \%(229 / 441)$ & $2.3 \%(10 / 441)$ & $45.8 \%(202 / 441)$ \\
\hline
\end{tabular}

Table 2: Temporal Clauses

It can be seen that present forms are generally rare in Bede. It is partly for this reason that most morphologically ambiguous forms occur in the preterite, a tendency increased as well by the greater degree of syncretism in this tense. As the different types of construction vary widely in their choice of mood, it may be best to deal with each type separately.

In clauses meaning 'before', the subjunctive seems to be universally preferred where the form is unambiguous; no identifiable examples of the indicative were found. Semantically, a situation presented from the perspective of a time at which it was still in the future may seem compatible with the use of a morphological category referring to an alternative world of evaluation; even in Modern English, there is often little 
difference between pairs such as before it happened/before it could happen. In Old English the use of the subjunctive seems to be independent of whether the event in question is known to have occurred:

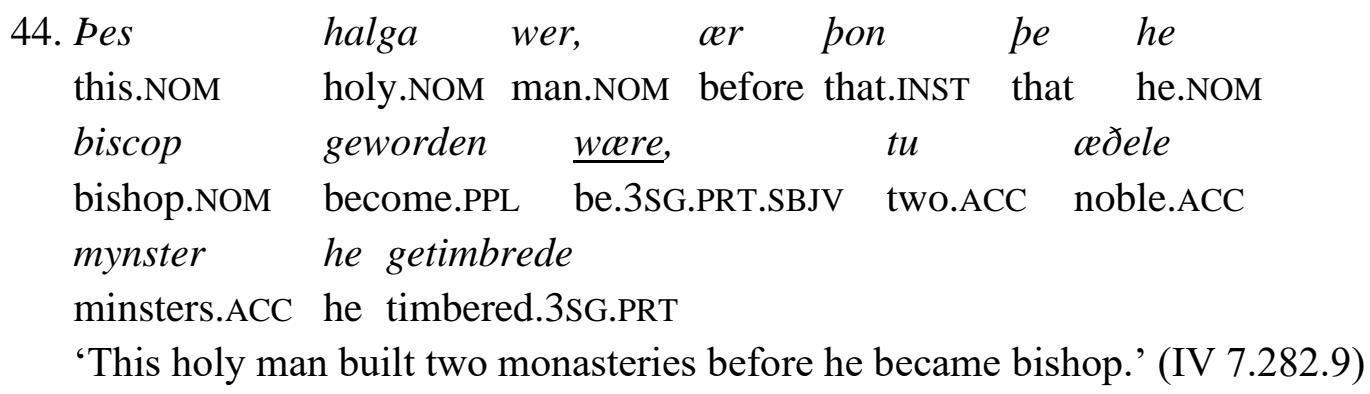

However, such sentences need not be seen as evidence that the choice of mood was syntactically governed by the conjunction here, while being free to vary more widely in other contexts. It may be more appropriate to propose that sentences such as the above reflect a practice of representing events in 'before'-clauses from the perspective of the original time, rather than from the moment of speech and the knowledge available to the speaker $\left(\mathrm{a}^{\mathrm{w}}<\mathrm{b}^{\exists \mathrm{w}}\right)$. Such a possible-world interpretation, making no commitment to whether or not the situation was eventually realized, has the potential for semantic compatibility with all contexts. The non-occurrence of the indicative in 'before'-clauses, though, means that no semantic distinctions can be made by the choice of mood other than those inherent in the conjunction, and its incremental contribution is therefore minimal.

Clauses meaning 'after' present the opposite situation; in these the mood found is normally indicative. However, most of these examples refer to situations whose occurrence was already certain both from the speaker's perspective and from the time of the main clause, and therefore it may be difficult to generalize about the rigidity of the association between the mood and the conjunction.

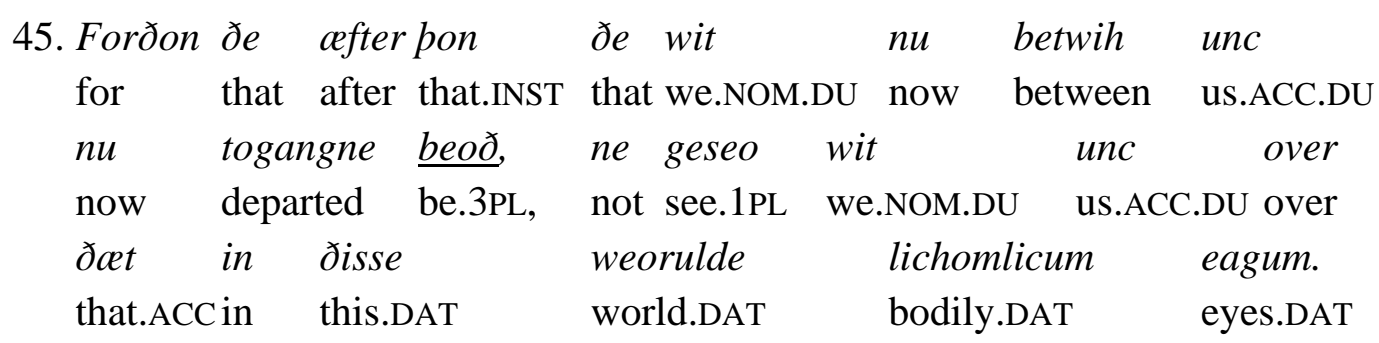

'For after we have now parted from each other, we shall never again see each other in this world with the eyes of the body.' (IV 30.372.2)

Only one example, (45), was found of an 'after'-clause referring to a future event, and here the event is regarded as certain by the speaker. The use of the indicative in these examples is not incompatible with the more general range of environments in which the indicative is used; in each clause the situation is described with reference to the actual world, a pattern represented in our model as $a^{w}>b^{w}$. Despite the scarcity of 
data, it seems possible to say at least that the incremental semantic contribution of mood in such clauses was no greater than elsewhere.

In clauses meaning 'when' or 'while', it can be seen that the indicative is used in the majority of morphologically unambiguous cases. Where the subjunctive does occur, its use is occasioned by factors independent of the temporal clause:

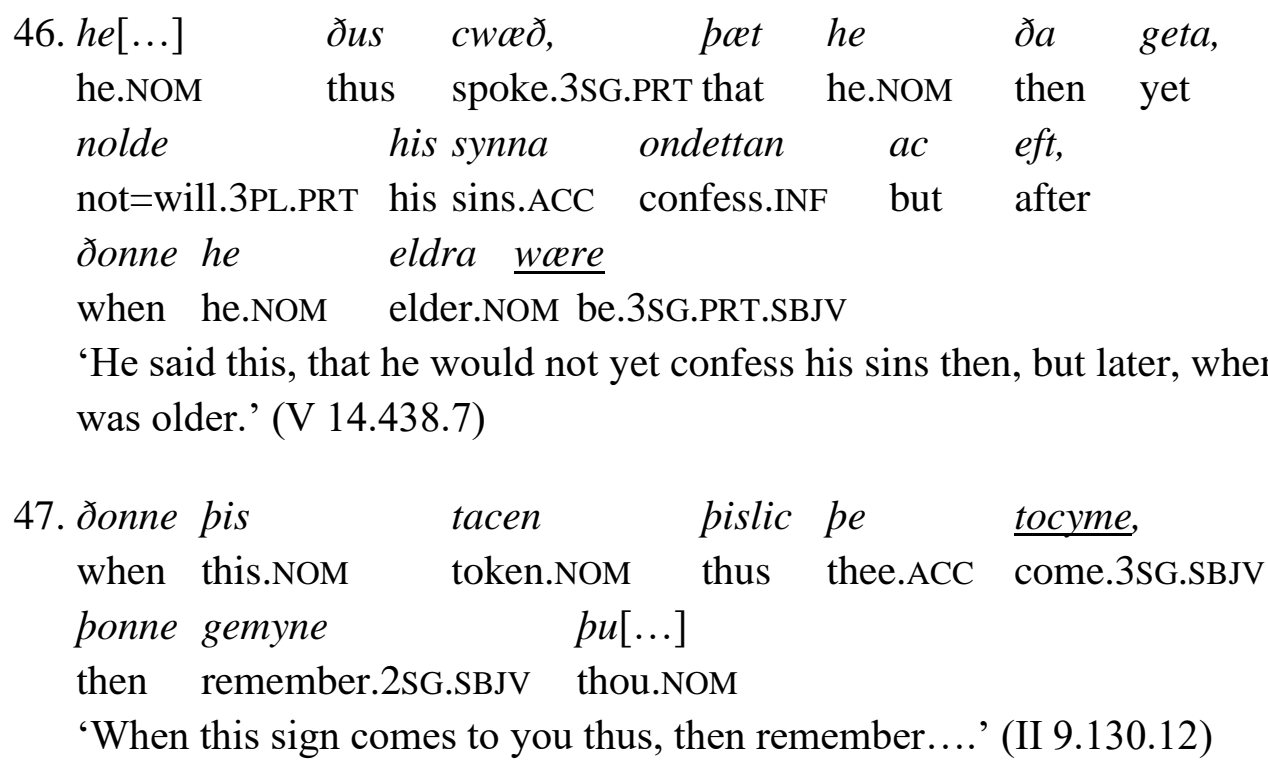

In both example (46) and (47), the subjunctive verb refers to an indefinite future occasion; in the former it is also embedded within indirect discourse (see Section 4.6), while in the latter example, it occurs in a broader context of directive illocutionary force (see Section 4.7 for similar phenomena in conditional clauses). A detailed discussion of the use of the subjunctive in clauses of this type is provided by Mitchell (1985: II, 308-337). For the present purposes, it may suffice to observe that when the subjunctive occurs in clauses meaning 'when' or 'while', its use is not related to the temporal meaning of the clause, but to other elements of the syntactic and semantic context. In (46), for example, where the subjunctive is found in a temporal clause within reported speech, it does not represent a relation of modality between be older and confess, but rather the combined relation of confess when older to say. In this way, the occurrence of the subjunctive within such a temporal clause is merely a specific case of its occurrence within complement clauses, as discussed in section 4.6 below.

With clauses meaning 'until', however, a different pattern appears. While the indicative is the most frequent form, the subjunctive is also used in these clauses, even in the absence of any external motivating factors. 
48. Đa stefne $[\ldots]$

the voices.NOM

oðpart he

until he.NOM to $\mathrm{him}$

to him.DAT sticcemalum nealecton,

bicwom to peacan

become.3SG.PRT
approached.3PL.PRT

'The voices drew closer to him little by little, until he reached the roof of the church.' (IV 3.264.21)

49. His lichoman [...] Eorconwald $[. .$.$] in portice hiscirican sumre$ his body.ACC Erconwald.NOM in porch.DAT his church.GEN.PL some.GEN geheold $[\ldots]$ oð patseo cirice gehalgod ware hold.3SG.PRT until the.NOM church.NOM hallowed be.3SG.PRT.SBJV 'Erconwald kept his body in the porch of one of his churches until the church was consecrated' (III 14.218.20)

50. Do

$$
\text { pis, } \quad \text { cwor }
$$

he,

do.2SG.IMP this.ACC say.3SG.PRT he.NOM until I.NOM back

after tide to ðe

cyme

after time.DAT to thee.DAT come.1SG.SBJV

“"Do this," he said, "until I come back to you after a time."” (IV 26.350.33) ${ }^{13}$

In all these cases, the original Latin verb was subjunctive ${ }^{14}$. As (50) shows, the subjunctive could be used even in cases where the meaning of the subordinate clause was purely temporal, with no intentional or causal relation between the two situations, while in (48) and (49) it is used to denote a situation known to have eventually occurred. If the variation in the Old English text was meaningful, it might be in keeping with the apparent meaning of the subjunctive in other contexts to suggest that its use presented the situation from a perspective in which the situation was not yet realized in the actual world. If this was so, 'until'-clauses may have provided an environment in which the subjunctive could make a meaningful incremental contribution to the discourse; it should be noted, though, that even here mood is not being used to signal truth-conditional properties such as the fulfilment or nonfulfilment of a situation.

It can be seen that in most temporal clauses the choice of mood is compatible with our semantic model in the sense that the indicative is used to represent situations in the actual world of the speaker and the subjunctive to represent situations in a possible world. In clauses meaning 'after', 'when', or 'while', the indicative is used except when additional cues exist to preclude an actual-world interpretation. In clauses meaning 'until', the meaning of the construction leaves speakers free to conceptualize

\footnotetext{
${ }^{13}$ Direct speech in itself is not normally associated with the subjunctive mood, e.g. III 13.200.2.

${ }^{14}$ The Latin conjunction donec, like oð pat, allowed the use of either the indicative or the subjunctive. The existence of such differences in mood between the two texts thus establishes the independence of the OE mood from the Latin original, and suggests that Bede and his translator may have conceived of the same event in different ways.
} 
a situation as actual or hypothetical, and consequently both moods are found; while the difference between the two moods is meaningful, the choice of mood would convey information relating to the speaker's concept of the situation rather than making truth-conditional assertions about its factuality. In 'before'-clauses, all unambiguous forms are subjunctive. Given the existence of meaningful subjunctives in other environments, it may be that the use of the subjunctive here forces a possibleworld interpretation, with the later situation being seen from a time-point before it became actual even if there is no doubt about its fulfilment in context. Alternatively, the use of subjunctive in 'before' clauses may be conventional and dictated by the conjunction which introduces it. The evidence does not allow us to tell these to interpretations apart. Many of the temporal clause types examined here are relatively recent developments, resulting from the transparent combination of prepositions and adverbs with originally nominal clauses (see Mitchell 1984). The existence of differences among them in mood selection is thus especially significant, suggesting an origin in the semantic differences among these similar structures.

\subsection{Causal clauses}

The most frequent expression of causality in Old English was the conjunction forpon, with its variants (e.g. forpom pe, forpy, etc.). A certain methodological issue is posed by the fact that these forms could mean not only 'because' but also 'for', 'therefore', or 'wherefore'. In this work the attempt has been made to focus only on those cases where the form in question serves as a subordinator, as elsewhere the use of mood would be expected to follow the patterns normal for main clauses; however, a number of potentially ambiguous cases exist that are subject to individual interpretation (for discussion see Mitchell 1985: II, 522-530). In some cases the Latin text provides an indication of the sense intended by the Old English translator, but there are a number of instances in which the two texts clearly differ in their choice of which clauses should be subordinated to which.

The choice of mood in causal clauses parallels that seen above for when-clauses. The few examples of subjunctives $(2.5 \%, 3 / 119)$ are all within indirect speech; it will be seen in section 4.6 below that the subjunctive mood is normal within indirect speech more generally. The remaining unambiguously marked forms $(53.8 \%, 64 / 119)$ are all indicative; while many examples $(43.7 \%, 52 / 119)$ are morphologically ambiguous, the distribution of the unambiguous forms suggests that the normal interpretation of these would most likely have been as indicatives.

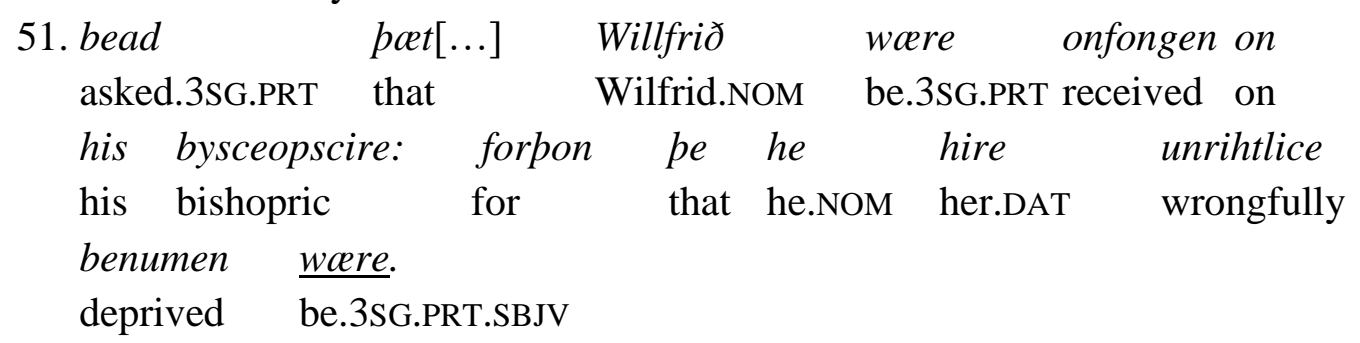


'...asked that Wilfrid should be received into his bishopric, as he had been wrongfully deprived of it.' (V 17.460.29)

No examples were found of the construction type encountered elsewhere (Mitchell 1985: II, 606-607) in which the subjunctive is used in a rejected condition. The observed distribution of mood could thus be accounted for with relative ease by assuming that causal clauses normally take the indicative, but that when they are embedded within other constructions affecting modality, a certain transparency exists so that the default indicative may be overridden by the semantic requirements of the higher clause.

\subsection{RESULT AND PURPOSE CLAUSES}

In Old English it was normally possible for clauses expressing purpose and result to be formed with the same conjunction, either pat(te) or compound forms such as swa pat or to pon pat. In general the indicative is used in result clauses, while the subjunctive is used in purpose clauses; this is unlike the situation in Latin, where despite the use of the same subordinator $u t$ in both cases, the subjunctive is mandatory.

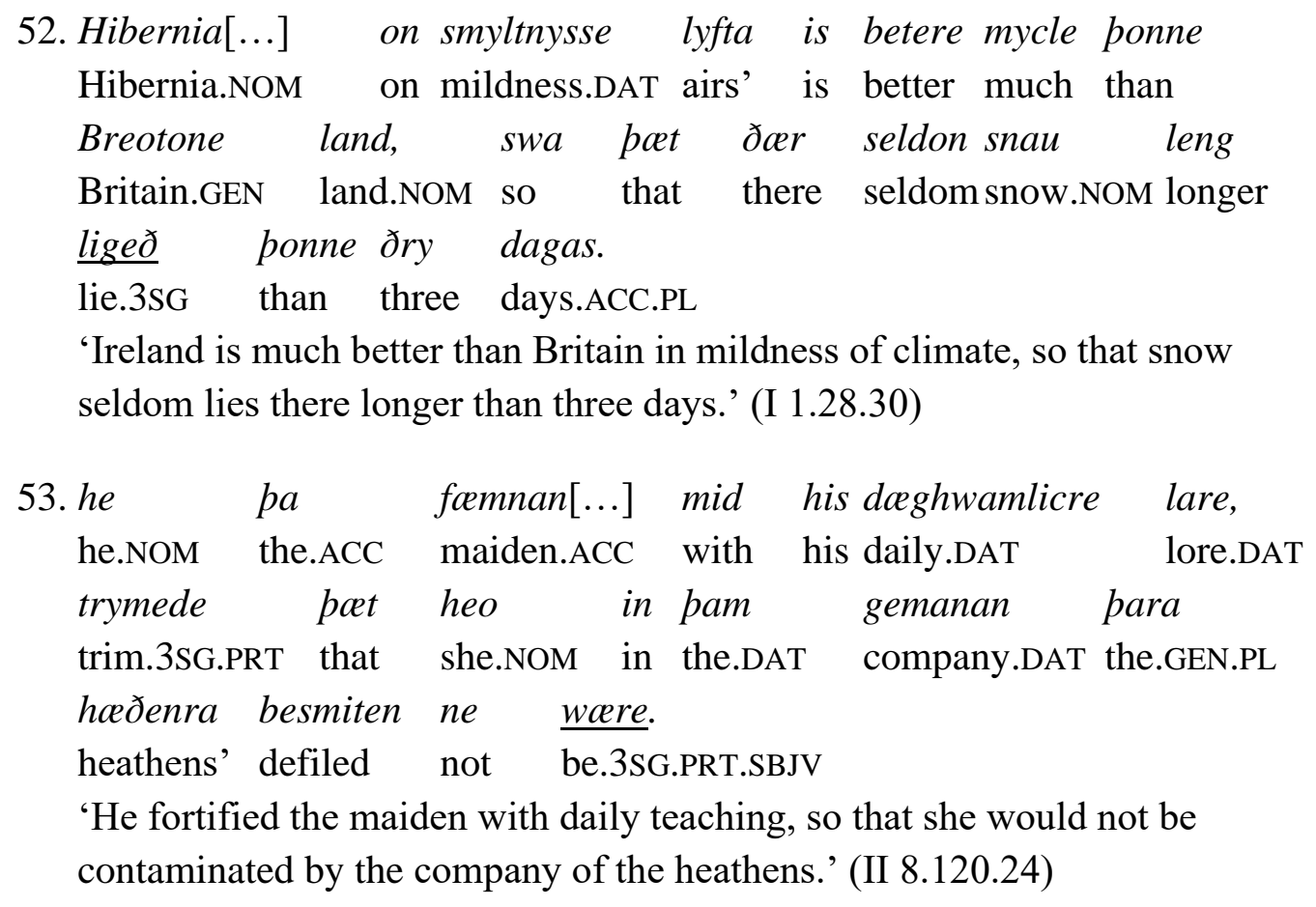

No identifiable counterexamples to this generalization were found among the 100 such constructions in our data; however, Mitchell (1985: II, 497) observes that in other texts the subjunctive sometimes occurs in result clauses referring to the effects of a hypothetical situation, and suggests that the absence of such constructions from Bede reflects the primarily factual nature of the subject matter. Conversely, examples such as (53) show that even purpose clauses referring to goals that are eventually achieved 
do not require the indicative (see further Mitchell 1985: II, 506-509); the broader context of this example makes it clear that the queen did remain a Christian, and so the goal expressed by ware was realized. The existence of a broad distinction between result and purpose clauses in their choice of mood fits well with our semantic model: the use of the indicative in result clauses reflects their use to describe situations in the actual world of the narrator, with the same world-reference as an indicative in a main clause would have, while the use of the subjunctive in purpose clauses reflects their interpretation with reference to a possible world embodying someone's goals. In this case the choice of mood also makes a greater incremental semantic contribution than in some other environments, by providing cues for the interpretation of a potentially ambiguous construction. However, a semantic contribution is also made by the choice of conjunction, in restricting the potential interpretation of the subordinate clause to result or purpose meaning; as the discussion on complement clauses will show, the ambiguity is resolved to a greater extent in the case of constructions such as to pon poet, which are used primarily for clauses of this sort, than those with the simple pat, which also has a variety of other uses.

\subsection{CONCESSIVE CLAUSES}

Concessive clauses in Old English present a relatively uncomplicated picture. The only conjunction in regular use for concessives is peah (be) 'though'. ${ }^{15}$

54. Ond peah ðe heora alderas forlorene waren, and though that their leaders.NOM forlorn be.3PL.PRT.SBJV ne meahte pat folc pa gen gereaht beon not may.3SG.PRT the.NOM folk.NOM then yet corrected be.INF 'And though their leaders had perished, yet the people still could not be corrected.' (II 5.114.4)

55. all oðer ping ða ge doð, peah heo all other.ACC things.ACC that ye.NOM do.2PL though they.NOM ussum peawum wiðerworde syn, we our.DAT customs.DAT contrary be.3PL.SBJV we.NOM gepyldelice arafnað. patiently perform.1PL 'All the other things that you do, though they may be contrary to our customs, we will carry out patiently.' (II 2.102.10)

All concessive constructions with unambiguous morphological marking (67.3\%, 37/55) were subjunctive. This includes constructions where the proposition conceded is known to be true, as in (54), and where both possibilities remain open, as in (55). It

\footnotetext{
${ }^{15}$ Other construction types examined here, such as temporal clauses and conditionals, could occasionally be used in contexts where they would be understood with concessive force.
} 
seems clear that mood could not be varied meaningfully in Old English concessive clauses; Mitchell (1985: II, 720-723) discusses the apparent lack of semantic motivation for the small number of indicative concessives observed elsewhere. In our model, concessive clauses would therefore be analysed in the same way as 'before'clauses, insofar as a single mood has come to prevail without reference to the context of a specific utterance. One possible factor in this is that the distinction between actual and hypothetical concessions is seldom relevant to the primary consideration, the apparent incongruity of two situations; as a result, the semantic differences between the two moods would be neutralized to some extent, so that in this case any tendency towards a fixed choice of mood would have little impact on comprehension.

\subsection{COMPLEMENT CLAUSES}

It has long been known that the choice of mood in Old English embedded clauses exhibits significant variation based on the choice of matrix verb (e.g. Gorrell 1895). However, less attention has been paid to the relative semantic contributions of the inflectional mood and of the matrix verb itself. In the present study our primary focus is on clauses whose syntactic role is the object or subject/predicate of a verb. More complex cases, such as clauses within prepositional phrases or headless relative clauses, can be more difficult to identify through the use of automated search queries; moreover, the syntactic differences between these constructions and complement clauses may make it more difficult to compare their semantic properties directly.

\begin{tabular}{|c|c|c|c|c|c|c|}
\hline & \multicolumn{3}{|c|}{ Present } & \multicolumn{3}{|c|}{ Past } \\
\hline & Indicative & Subjunctive & Ambiguous & Indicative & Subjunctive & Ambiguous \\
\hline ætiewan 'reveal' & - & - & - & $100 \%(1 / 1)$ & - & - \\
\hline ætycan 'increase' & - & - & - & - & - & $100 \%(1 / 1)$ \\
\hline andettan 'confess' & $100 \%(1 / 1)$ & - & - & - & - & - \\
\hline $\begin{array}{l}\text { andswarian } \\
\text { 'answer' }\end{array}$ & - & - & - & - & $50.0 \%(1 / 2)$ & $50.0 \%(1 / 2)$ \\
\hline \begin{tabular}{|l|} 
awritan \\
'write (down)'
\end{tabular} & - & - & - & - & $100 \%(1 / 1)$ & - \\
\hline $\begin{array}{l}\text { bebeodan } \\
\text { 'command' }\end{array}$ & - & $11.1 \%(1 / 9)$ & - & - & $33.3 \%(3 / 9)$ & $55.6 \%(5 / 9)$ \\
\hline $\begin{array}{l}\text { becuman } \\
\text { 'come (to mind)' }\end{array}$ & - & - & - & $50.0 \%(1 / 2)$ & - & $50.0 \%(1 / 2)$ \\
\hline \begin{tabular}{|l|} 
behealdan \\
'endeavour'
\end{tabular} & - & - & - & - & - & $100 \%(1 / 1)$ \\
\hline beon 'be' & - & - & - & - & - & $100 \%(1 / 1)$ \\
\hline $\begin{array}{l}\text { beswapan } \\
\text { 'persuade' }\end{array}$ & - & $100 \%(1 / 1)$ & - & - & - & - \\
\hline bewerian 'forbid' & - & - & $25.0 \%(1 / 4)$ & - & $50.0 \%(2 / 4)$ & $25.0 \%(1 / 4)$ \\
\hline biddan 'ask, bid' & - & $13.2 \%(5 / 38)$ & - & - & $34.2 \%(13 / 38)$ & $52.6 \%(20 / 38)$ \\
\hline blissian 'rejoice' & - & - & - & - & $100 \%(1 / 1)$ & - \\
\hline
\end{tabular}




\begin{tabular}{|c|c|c|c|c|c|c|}
\hline 'cuman & - & - & - & $100 \%(1 / 1)$ & - & - \\
\hline cunnan 'know' & $50.0 \%(1 / 2)$ & - & - & $50.0 \%(1 / 2)$ & - & - \\
\hline cweðan 'say' & - & - & - & $6.3 \%(1 / 16)$ & $31.3 \%(5 / 16)$ & $62.5 \%(10 / 16)$ \\
\hline $\begin{array}{l}\text { cyðan } \\
\text { 'make known' }\end{array}$ & - & - & $33.3 \%(1 / 3)$ & - & - & $66.7 \%(2 / 3)$ \\
\hline $\begin{array}{l}\text { deman } \\
\text { 'determine' }\end{array}$ & - & - & - & - & - & $100 \%(1 / 1)$ \\
\hline findan 'find' & - & - & - & - & $100 \%(1 / 1)$ & - \\
\hline $\begin{array}{l}\text { forecweðan } \\
\text { 'foretell' }\end{array}$ & - & - & - & - & $100 \%(1 / 1)$ & - \\
\hline $\begin{array}{l}\text { foreseon } \\
\text { 'provide' }\end{array}$ & - & $50.0 \%(1 / 2)$ & - & - & - & $50.0 \%(1 / 2)$ \\
\hline forgiefan 'offer' & - & - & - & - & - & $100 \%(1 / 1)$ \\
\hline forlætan 'permit' & - & - & - & - & $100 \%(1 / 1)$ & - \\
\hline $\begin{array}{l}\text { forswigian } \\
\text { 'conceal' } \\
\end{array}$ & - & - & - & - & - & $100 \%(1 / 1)$ \\
\hline \begin{tabular}{|l} 
gebeodan \\
'command'
\end{tabular} & - & - & - & - & - & $100 \%(1 / 1)$ \\
\hline $\begin{array}{l}\text { gedafenian } \\
\text { 'behove' }\end{array}$ & - & $100 \%(1 / 1)$ & - & - & - & - \\
\hline gefeon 'rejoice' & - & - & - & - & - & $100 \%(1 / 1)$ \\
\hline gehatan 'promise' & - & - & - & - & $33.3 \%(1 / 3)$ & $66.7 \%(2 / 3)$ \\
\hline $\begin{array}{l}\text { gehieran } \\
\text { 'hear, listen to' }\end{array}$ & - & - & - & - & $100 \%(2 / 2)$ & - \\
\hline gehyhtan 'hope' & - & - & - & - & $100 \%(1 / 1)$ & - \\
\hline geleornian 'learn' & - & - & - & - & - & $100 \%(1 / 1)$ \\
\hline gelician 'please' & - & - & - & - & - & $100 \%(1 / 1)$ \\
\hline geliefan 'believe' & - & $16.7 \%(1 / 6)$ & - & - & $16.7 \%(1 / 6)$ & $66.7 \%(4 / 6)$ \\
\hline \begin{tabular}{|l} 
gelimpan \\
'happen' \\
\end{tabular} & $8.3 \%(1 / 12)$ & - & - & $75.0 \%(9 / 12)$ & - & $16.7 \%(2 / 12)$ \\
\hline $\begin{array}{l}\text { gemunan } \\
\text { 'remember' }\end{array}$ & - & $100 \%(1 / 1)$ & - & - & - & - \\
\hline $\begin{array}{l}\text { gemyndgian } \\
\text { 'recall' }\end{array}$ & - & - & - & $100 \%(1 / 1)$ & - & - \\
\hline $\begin{array}{l}\text { geortriewan } \\
\text { 'doubt' }\end{array}$ & $100 \%(1 / 1)$ & - & - & - & - & - \\
\hline geseon 'see' & - & $50.0 \%(2 / 4)$ & - & $50.0 \%(2 / 4)$ & - & - \\
\hline gepafian 'permit' & - & - & - & - & - & $100 \%(1 / 1)$ \\
\hline gepencan 'think' & $50.0 \%(1 / 2)$ & - & - & $50.0 \%(1 / 2)$ & - & - \\
\hline $\begin{array}{l}\text { gepristlæcan } \\
\text { 'presume' }\end{array}$ & - & - & - & - & - & $100 \%(1 / 1)$ \\
\hline halsian 'entreat' & - & $57.1 \%(4 / 7)$ & - & - & $42.9 \%(3 / 7)$ & - \\
\hline hatan 'order, bid' & - & - & - & - & $50.0 \%(1 / 2)$ & $50.0 \%(1 / 2)$ \\
\hline herian 'approve' & - & - & - & $100 \%(1 / 1)$ & - & - \\
\hline
\end{tabular}




\begin{tabular}{|l|c|c|c|c|c|c|}
\hline $\begin{array}{l}\text { hwierfan 'turn } \\
\text { (into a proverb)' }\end{array}$ & - & - & - & - & - & $100 \%(1 / 1)$ \\
\hline læran 'teach' & - & $33.3 \%(1 / 3)$ & - & - & - & $66.7 \%(2 / 3)$ \\
\hline leornian 'learn' & $33.3 \%(1 / 3)$ & - & - & $33.3 \%(1 / 3)$ & - & $33.3 \%(1 / 3)$ \\
\hline lician 'please' & - & $20.0 \%(1 / 5)$ & - & - & - & $80.0 \%(4 / 5)$ \\
\hline $\begin{array}{l}\text { manian } \\
\text { 'admonish' }\end{array}$ & - & $20.0 \%(1 / 5)$ & - & - & $20.0 \%(1 / 5)$ & $60.0 \%(3 / 5)$ \\
\hline $\begin{array}{l}\text { metan } \\
\text { 'meet (with)' }\end{array}$ & - & $100 \%(1 / 1)$ & - & - & - & - \\
\hline niedan 'compel' & - & - & - & - & - & $100 \%(1 / 1)$ \\
\hline $\begin{array}{l}\text { oncnawan } \\
\text { 'understand' }\end{array}$ & - & - & - & - & - & $100 \%(2 / 2)$ \\
\hline ondrædan 'dread' & - & - & - & - & - & $100 \%(1 / 1)$ \\
\hline $\begin{array}{l}\text { ongietan } \\
\text { 'perceive' }\end{array}$ & - & - & - & $44.4 \%(4 / 9)$ & $11.1 \%(1 / 9)$ & $44.4 \%(4 / 9)$ \\
\hline $\begin{array}{l}\text { ræswan } \\
\text { 'consider' }\end{array}$ & - & - & - & - & $100 \%(1 / 1)$ & - \\
\hline secgan 'say' & $10.0 \%(3 / 30)$ & - & $3.3 \%(1 / 30)$ & $3.3 \%(1 / 30)$ & $40.0 \%(12 / 30)$ & $43.3 \%(13 / 30)$ \\
\hline stihtan 'ordain' & - & - & - & - & $100 \%(1 / 1)$ & - \\
\hline $\begin{array}{l}\text { tellan } \\
\text { 'tell, believe' }\end{array}$ & - & - & - & - & $100 \%(1 / 1)$ & - \\
\hline bafian 'permit' & - & - & - & - & $100 \%(1 / 1)$ & - \\
\hline $\begin{array}{l}\text { bencan 'think' } \\
\text { bingian 'arrange' }\end{array}$ & - & - & - & - & - & $100 \%(1 / 1)$ \\
\hline byncan 'seem' & - & $25.0 \%(1 / 4)$ & - & - & $75.0 \%(3 / 4)$ & - \\
\hline toætycan 'add' & - & - & - & - & $100 \%(1 / 1)$ & - \\
\hline $\begin{array}{l}\text { tweon 'doubt' } \\
\text { wenan 'hope' }\end{array}$ & - & - & - & $100 \%(1 / 1)$ & - & - \\
\hline $\begin{array}{l}\text { weorðan } \\
\text { 'come to pass' }\end{array}$ & - & - & - & - & $50.0 \%(1 / 2)$ & $50.0 \%(1 / 2)$ \\
\hline wesan 'be' & - & $37.5 \%(3 / 8)$ & $12.5 \%(1 / 8)$ & $12.5 \%(1 / 8)$ & $12.5 \%(1 / 8)$ & $25.0 \%(2 / 8)$ \\
\hline $\begin{array}{l}\text { wilnian 'desire' } \\
\text { witan 'know' }\end{array}$ & - & - & - & - & $50.0 \%(1 / 2)$ & $50.0 \%(1 / 2)$ \\
\hline writan 'write' & - & - & - & $100 \%(1 / 1)$ & - & - \\
\hline
\end{tabular}

\section{Table 3: Complement Clauses ${ }^{16}$}

Although many of the individual lexemes shown above are sparsely attested, it can be seen that most of them show no variation in mood. In many cases, morphologically ambiguous forms are found, but these would presumably have been interpreted by speakers on the basis of semantic compatibility with the context and with the matrix verb. For example, with a verb such as witan 'know', which our semantic model describes as having w-type modality and which is not found with unambiguous subjunctive forms, we would expect speakers to interpret ambiguous forms as

\footnotetext{
${ }^{16}$ The glosses above reflect the most frequent meaning within the examples from Bede, which may not always be the primary sense in Old English as a whole.
} 
indicative. The only verbs that show unambiguous evidence of variation in mood are cweðan, geseon, ongietan, secgan, and wesan. Among these, the choice of mood seems to be most salient for geseon; the indicative examples have the sense 'perceive', while the subjunctive examples have the sense 'see to it, ensure'.

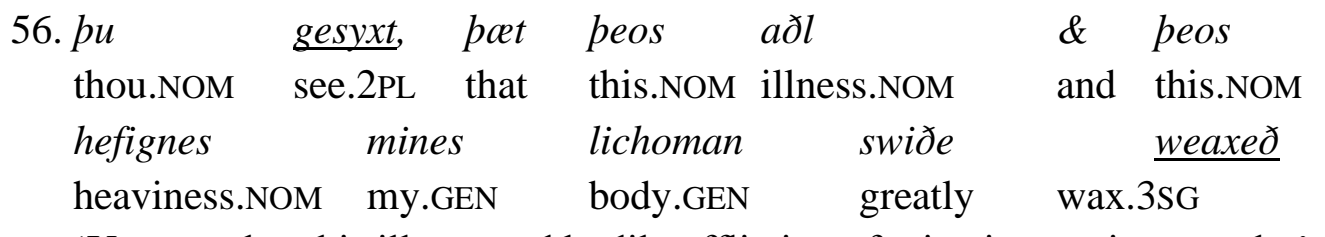

'You see that this illness and bodily affliction of mine is growing greatly.' (III 11.190.16)
57. geseoh pat bu ut ponon ne gonge, ar seo see.2SG.IMP that thou.NOM out thence not go.2SG.SBJV ere the.NOM aðl from be gewiten sy illness.NOM from thee.DAT departed be.3SG.SBJV

'See that you do not go outside before the illness has departed from you.' (III 10.186.26)

In the case of ongietan and wesan, it is possible to see some degree of correlation between the choice of mood and the context of the utterance. In general, the indicative examples seem to describe specific situations known to exist in the actual world of the narrator. The subjunctive examples refer to more general types of situations, in contexts in which the actual existence of the situation is not the primary issue, in keeping with the fact that they are embedded within constructions that are themselves subjunctive; these examples are not sufficiently numerous to determine whether the decisive factor is the presence of another subjunctive per se or a more general semantic property such as world reference.

58. Forðon Osweo
For Soðlice

$\begin{array}{llll}\text { 59. paet ware } & \text { rihtlic to } & \text { ongeotanne, patte ealle } \\ \text { that be.3SG.PRT.SBJV } & \text { rightly to } & \text { perceive.INF.DAT that all } \\ \text { pa } & \partial e \quad \text { his } & \text { willan } & \text { leornode \& worhte, } \\ \text { those.NOM that his will.ACC } & \text { learn.3SG.PRT and work.3SG.PRT } \\ \text { from pam } & \text { be hy } & \text { gescepene waron, pat heo } \\ \text { from whom.DAT that they.NOM } & \text { shaped be.3PL.PRT that they.NOM }\end{array}$




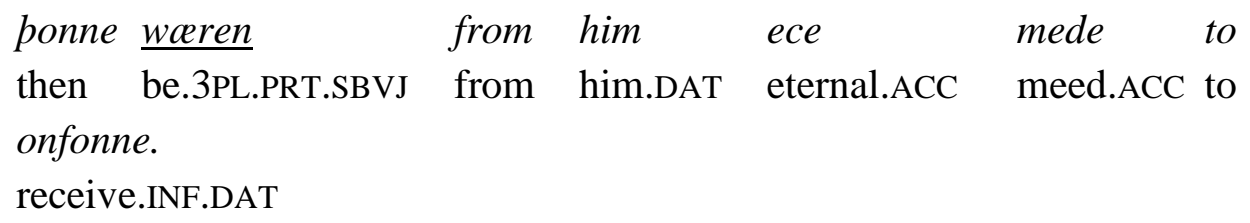

'It should rightly be recognized that all those who learned and did the will of Him by Whom they were created, that they would receive an eternal reward from Him.' (III 16.224.22) ${ }^{17}$

With verbs of speaking, the mood of complement clauses is known to vary in ways that are not yet fully understood, based on factors including, but not limited to, the choice of matrix verb (see Mitchell 1985: II, 48-59). For our present purposes, it may be most relevant to remark that, as examples (60)-(63) show, the matrix verb and the world reference of the embedded proposition are not sufficient in themselves to determine the mood of the embedded clause, and yet the choice of mood seems to have little effect on the semantics of the resulting sentence.
60. Bi pam arestan we bufan cwadon, pat he by the.DAT first we.NOM above say.1PL.PRT that he.NOM $\begin{array}{llll}\text { waere } & \text { in Eoforwiicceastre to biscope } & \text { gehalgad. } \\ \text { be.3SG.PRT.SBJV } & \text { in York.DAT } & \text { to bishop.DAT } & \text { hallowed }\end{array}$ 'Of the first we have said above that he was consecrated as bishop at York.' (IV 24.334.24)
61. Bi paem neahstan twam her is after to cweðanne, pat by the.DAT next.DAT two.DAT here be.3SG after to say.INF.DAT that heora se aresta was at Heagostealdes ea, their the.NOM first.NOM be.3SG.PRT at Hexham.DAT ond se aftera was in Eoforwiicceastre to and the.NOM after.NOM be.3SG.PRT in York.DAT to biscope gehalgad. bishop hallowed 'Of the next two it is to be said below that the former was consecrated as bishop at Hexham and the latter at York.' (IV 24.334.27) ${ }^{18}$

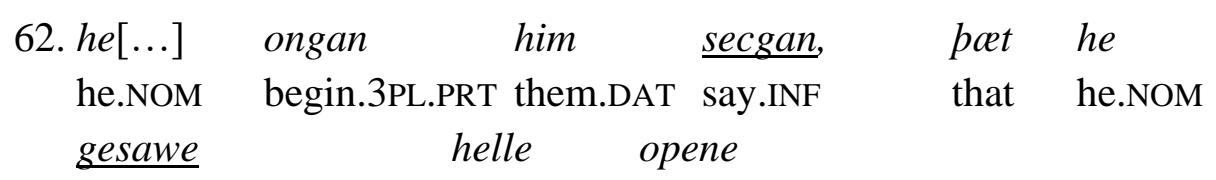

\footnotetext{
${ }^{17}$ Some potential syntactic ambiguity is present in this sentence, so that the subordinate clause may be seen either as the object of ongeotanne or as in apposition to the initial pat. In either case the same semantic analysis would apply here.

${ }^{18}$ As above, it is also possible to see the embedded clause as the subject of is rather than the object of cweðanne. On such a view, what would need to be explained is the difference in mood between this example and (59).
} 
saw.3PL.PRT.SBJV hell.NOM open

'He began to say to them that he saw Hell open.' (V 15.442.26) 
63. Forðonic ðe secge pat pu nu bist for I.NOM thee.DAT say.1SG that thou.NOM now be.2SG hradlice fram pysse untrumnesse geholed. quickly from this.DAT illness.DAT healed 'Therefore I say to you that you will now be quickly healed of this illness.' (V 17.462.28)

\begin{tabular}{|l|c|c|c|c|c|c|}
\cline { 2 - 7 } \multicolumn{1}{c|}{} & \multicolumn{4}{c|}{ Present } & \multicolumn{3}{c|}{ Past } \\
\cline { 2 - 7 } \multicolumn{1}{c|}{} & Indicative & Subjunctive & Ambiguous & Indicative & Subjunctive & Ambiguous \\
\hline Causative & - & $36.4 \%(4 / 11)$ & - & - & $9.1 \%(1 / 11)$ & $54.5 \%(6 / 11)$ \\
\hline Commissive & - & - & - & - & $25.0 \%(1 / 4)$ & $75.0 \%(3 / 4)$ \\
\hline Directive & - & $20.3 \%(13 / 64)$ & - & - & $34.4 \%(22 / 64)$ & $45.3 \%(29 / 64)$ \\
\hline Emotive & - & $10.0 \%(1 / 10)$ & - & $10.0 \%(1 / 10)$ & $10.0 \%(1 / 10)$ & $70.0 \%(7 / 10)$ \\
\hline Existential & $7.4 \%(2 / 27)$ & - & - & $55.6 \%(15 / 27)$ & $3.7 \%(1 / 27)$ & $33.3 \%(9 / 27)$ \\
\hline Factive & - & - & - & $100 \%(2 / 2)$ & - & - \\
\hline Implicative & - & - & - & - & - & $100 \%(1 / 1)$ \\
\hline Intention & - & - & - & $50.0 \%(1 / 2)$ & - & $50.0 \%(1 / 2)$ \\
\hline Knowledge & $57.9 \%(11 / 19)$ & - & $10.5 \%(2 / 19)$ & $15.8 \%(3 / 19)$ & - & $15.8 \%(3 / 19)$ \\
\hline Modal & - & $100 \%(2 / 2)$ & - & - & - & - \\
\hline Negative & - & - & $16.7 \%(1 / 6)$ & - & $50.0 \%(3 / 6)$ & $33.3 \%(2 / 6)$ \\
\hline Perception & $4.2 \%(1 / 24)$ & $8.3 \%(2 / 24)$ & - & $33.3 \%(8 / 24)$ & $29.2 \%(7 / 24)$ & $25.0 \%(6 / 24)$ \\
\hline Preference & - & $25.0 \%(2 / 8)$ & $12.5 \%(1 / 8)$ & - & $25.0 \%(2 / 8)$ & $37.5 \%(3 / 8)$ \\
\hline Statement & $6.6 \%(4 / 61)$ & - & $3.3 \%(2 / 61)$ & $4.9 \%(3 / 61)$ & $36.1 \%(22 / 61)$ & $49.2 \%(30 / 61)$ \\
\hline Thought & $7.1 \%(1 / 14)$ & $7.1 \%(1 / 14)$ & - & $14.3 \%(2 / 14)$ & $21.4 \%(3 / 14)$ & $50.0 \%(7 / 14)$ \\
\hline
\end{tabular}

Table 4: Complement clauses by semantic class

A similar pattern emerges when the distribution of mood in complement clauses is considered in relation to the meaning of the matrix verb. In Table 4, the verbal lexemes are aggregated on the basis of semantic category, using a classification based on that in Portner (2018: 72-3). It can be seen that a considerable degree of homogeneity exists not only for individual lexemes but for these broader categories. The existence of associations between such categories and mood (e.g. knowledge with indicatives, directives with subjunctives) means that within these categories at least, while the world reference of the construction is semantically compatible with the choice of inflectional mood, this reference could for the most part be predicted from the meaning of the matrix verb alone. As a result, there would be less need for such distinctions to be signalled morphologically.

Although a relatively large number of factors interact in producing the observed distribution of mood in complement clauses, some generalizations may still be made. While there are no clear counterexamples to our proposed semantic analysis, there are environments in which the semantic difference between indicatives and subjunctives may be neutralized to some extent, where situations that exist in the actual world can 
be presented as such but need not be. This can result in the co-occurrence of indicatives and subjunctives in the same environment, as in the following example:

64. Writed Eutropius pat Constantinus se
writes.3SG Eutropius.NOM that Constantine.NOM the.NOM
casere $\quad \frac{\text { ware }}{\text { Caesar.NOM be.3SG.PRT.SBJV on Britain.DAT begotten and }}$
after his fader to rice feng.
after his father.DAT to kingdom.DAT take.3SG.PRT.IND
'Eutropius writes that the Emperor Constantine was born in Britain and
succeeded to the throne after his father.' (I 8.42.17)

Because of this neutralization, and because the matrix verb, by expressing concepts such as knowledge or perception, can indicate world reference in a relatively finegrained manner, the incremental contribution of inflectional mood in such environments is relatively low. However, the choice of mood was not fully deterministic. There are some constructions, such as those with geseon, in which either mood could be used in order to affect the truth-conditional content of the sentence. Moreover, the variation observed with verbs such as secgan may represent a meaningful opposition between the two moods. Although the exact nature of this opposition is less clear from the data, it might be consistent with the patterns seen in other constructions to suggest that as the subjunctive was more common, the use of the indicative may have imposed an explicitly ' $w$ ' reading; no examples incompatible with this hypothesis have been found in the data. However, by Middle English the indicative had become clearly established as the unmarked mood for indirect discourse (e.g. Fischer 1992: 314); as the OE variation in mood has no clear equivalent in the later language, it may be inferred that the loss of its communicative functions had little lasting impact.

\subsection{CONDITIONAL SENTENCES}

In conditional constructions it is possible for speakers to vary not only mood but tense to a greater degree than is possible in many of the dependent constructions examined above. The interaction of tense and mood with other semantic components of conditional clauses is a complex and still controversial topic (see e.g. Stalnaker 2014: 148-188); while it is beyond the scope of the present work to provide a comprehensive semantic model of conditionals, the data from Bede can shed light on the relative semantic contributions of tense and mood at this stage of the language. In most cases the two categories do not vary independently; real conditionals (i.e. those represented in a 'w'-type situation according to our model) are expressed with the present indicative in both clauses, while unreal conditionals (i.e. those represented in a ' $\exists w$ ' or ' $\neq w$ '-type world) are expressed with the past subjunctive. 
65. $n u$ gif Agustinus $\underline{i s}$ milde \& eaðmodre heortan, now if Augustine.NOM be.3sG mild and humble.GEN heart.GEN ponne $\underline{i s}$ he gelyfed pat he Cristes

then be.3SG he.NOM permitted that he Christ.GEN geoc bere

yoke.ACC bear.3SG.SBJV

'Now if Augustine is mild and of humble heart, then it is permitted for him to bear the yoke of Christ.' (II 2.100.25)

66. gif ic nu in oðrum life ware, ponne

if I.NOM now in other.DAT life.DAT be.1SG.PRT.SBJV then

ware $\min$ sawl par purh his pingunge

be.3SG.PRT.SBJV my soul there through his intercession.DAT

from pam bendum \& witum onlysed.

from the.DAT eternal.DAT bonds.DAT and torments.DAT released

'If I were now in the other world, then my soul there would be released from the eternal bonds and torments through his intercession.' (IV 23.328.11)

67. Pat lif he oft \& geara wolde

that.ACC life.ACC he.NOM often and readily will.3SG.PRT

geceosan[...] gif him ne wiðstode pat

choose.INF if him.DAT not withstand.3SG.PRT.SBJV the.NOM

wiðerworde mod his wiifes.

contrary.NOM mood.NOM his wife.GEN

'He would have chosen that life often and readily, if his wife's opposing views had not stood in his way.' (IV 14.294.8)

Of 198 conditionals found, only $43(21.7 \%)$ clearly depart from this pattern, but it is perhaps these departures that merit the most attention.

68. Gif ponne swiðra wind aras,

if then stronger.NOM wind.NOM arise.3SG.PRT

ponne tynde he his bec

then close.3SG.PRT he.NOM his books.ACC

'If a stronger wind then arose, then he used to close his books.' (IV 3.268.18)

69. Gifhe feaht, ne was he gehafted.

if he.NOM fight.3SG.PRT not be.3SG.PRT he.NOM captured

'If he [St. Paul] fought, he was not captive.' (I 16.88.22)

Some past indicative conditionals are found simply as the past-time counterparts of present indicative conditionals, expressing the habitual or logical consequences of events in the past. The use of the indicative in these constructions is in accordance with our proposed semantic model, given that reference is to the actual world of the 
narrator; the scarcity of such forms relative to present indicative conditionals is due simply to less frequent occurrence of contexts in which such conditionals would be appropriate. In other cases a conditional has a past subjunctive in the protasis, but a past indicative in the apodosis:

70. Ja he heht $\begin{aligned} & \text { him } \\ & \text { then order.3SG.PRT.IND he.NOM them.DAT barley-seed.ACC bring.INF }\end{aligned}$
gif wen ware, $\quad$ bat pat wexan wolde
if hope be3SG.PRT.SBJV that that.NOM wax.INF will.3SG.PRT
'Then he told them to bring barley seed, if there were a possibility that this
would grow.' (IV 29.366.26)

In constructions of this sort, 'if' is almost equivalent to 'in case'; the apodosis uses the indicative to refer to an event that is asserted to have taken place independently of the conditional. A similar independence of mood, and lack of causal relationship, can also be found in certain 'biscuit conditionals', of the sort described by Austin (1961) (e.g. If you want a biscuit, there are some on the sideboard).
71. Ic seolfa cuðe
sumne broðar[...], ðas noman I.NOM self.NOM can.1SG.PRT some.ACC brother.ACC whose name.ACC ic eac swylce genemnan mag, gif ðat owiht brycia. I also such name.INF may.1sG if that.NOM aught profit.3sG.SBJV 'I myself knew a certain brother, whose name I can likewise name if that would be of any use.' (V 15.442.9)

The most frequent occurrence of the present subjunctive in conditionals, though, is in 'volitional expressions'; this term was used by Behre (1934) to describe a semantic category encompassing a syntactically heterogeneous array of constructions including imperatives, jussive subjunctives, modal propositions, and reported desires.

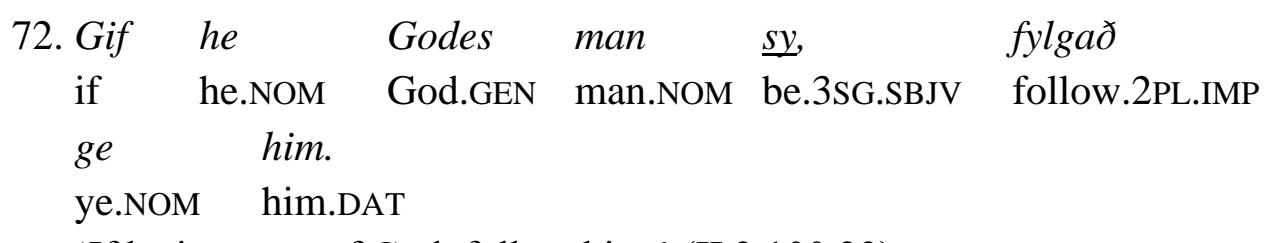

'If he is a man of God, follow him.' (II 2.100.23)

$\begin{array}{lllll}\text { 73. gif } & \text { he rihtlice } & \text { cristen beon } & \text { wille, } \\ \text { if } & \text { he.NOM rightly } & \text { Christian } & \text { be.NIM } & \text { will.3SG.SBJV } \\ \text { ne } & \text { gegaderie } & \text { he } & \text { hine to angum oðrum } \\ \text { not } & \text { gather.3SG.SBJV he.NOM him.ACC to any.DAT other.DAT }\end{array}$
'If he truly wishes to be a Christian, let him not gather himself to any other.' (IV 5.280.3) 


74. nemne he mid watre apwegen \& bibaðod
unless he.NOM with water.DAT washed and bathed
sy, ne sceal he in circan $\quad$ gongan
be.3SG.SBJV not shall.3SG he.NOM in church.DAT go.INF
'Unless he is washed and bathed in water, he shall not go into the church' (I
16.80.22)

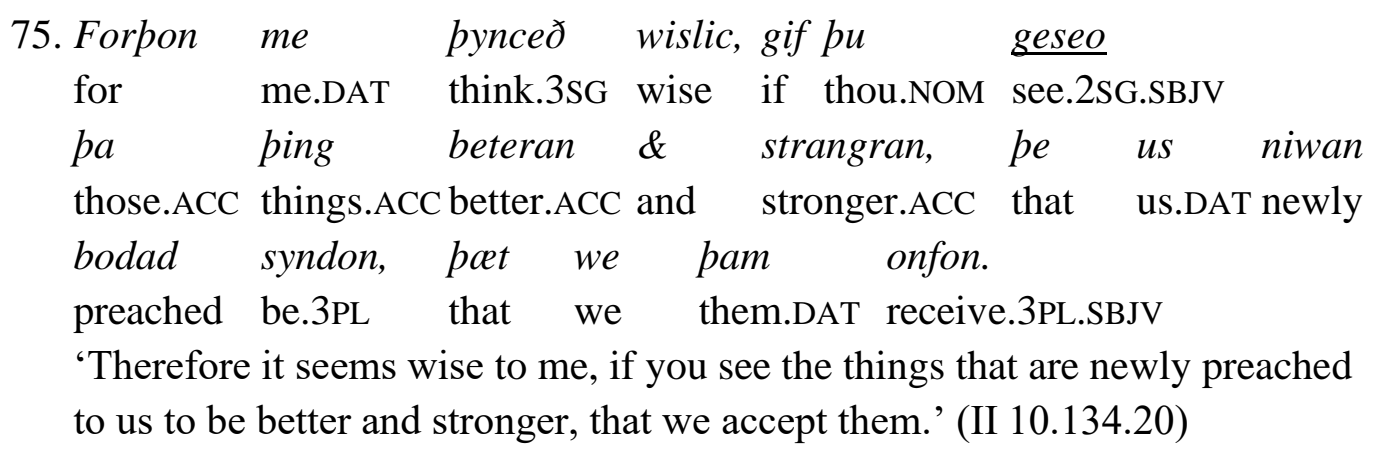

The environments in which the present subjunctive is found thus seem to be linked by their semantic properties, a phenomenon that accords with the semantic explanation proposed in our model. The use of the present subjunctive in such environments does not seem merely to reflect the speaker's desire to present a situation as hypothetical, as with a typical past subjunctive conditional. Yet even where the proposition expressed by the protasis may already be true in the actual world, as in the last example, it is not presented merely as a situation to be described, but as a precondition for future action. From a syntactic perspective, sentences such as (74) and (75) can be interpreted as embedded conditionals, so that the entire conditional is under the scope of a verb such as sculan ${ }^{19}$ or pyncan, with subsequent movement of the if-clause; such an explanation would allow these cases to be treated in the same way as (72) and (73), where the protasis is clearly embedded under an imperative or jussive subjunctive. ${ }^{20}$ From the perspective of our model, the prevalence of the subjunctive in such constructions can be seen as reflecting a tendency to present the conditions upon which situations whose fulfilment is requested or commanded, and which are thus ' $\exists w$ ', from the same ' $\exists w$ ' perspective.

Even in this brief survey of the types of conditional construction present in Bede, certain patterns are visible. The use of the moods in conditionals corresponds to what our semantic model would predict: the indicative is used in real ('w') conditionals, while the subjunctive is used not only in unreal (' $\exists \mathrm{w}$ ' or ' $\neq \mathrm{w}$ ') conditionals but in contexts referring to some situation desired or bidden to take place in the future. At

\footnotetext{
${ }^{19}$ There is no complete consensus regarding the extent to which OE modals had diverged syntactically from other verbs, but the proposed approach could be used, mutatis mutandis, with both monoclausal and biclausal analyses of these constructions.

${ }^{20}$ The indicative does sometimes occur even in the presence of 'volitional expressions'. Although unambiguous examples exist in other texts, the only possible exceptions in Bede (e.g. I 16.64.25) can potentially be viewed as the conflation of indicative synd 'are' and subjunctive syn (Mitchell 1985: II, 789).
} 
the same time, much of the semantic contribution of mood is duplicated by the effect of tense marking, so that there are relatively few cases where mood is the sole cue used by speakers to interpret conditionals; this is especially relevant given the growing tendency towards morphological syncretism between indicative and subjunctive in the preterite, and the corresponding frequency of modally ambiguous forms. Nevertheless, the existence of modal contrasts between constructions such as past indicative and past subjunctive conditionals shows that despite the infrequency of such contrasts, mood is still potentially available to speakers as a means of making salient semantic distinctions.

\subsection{MOOD AND MODALS}

An additional factor interacting with mood in Old English is speakers' use of modals. Verbs such as cunnan 'can', magan 'may', sculan 'shall', and willan 'will', even before they had reached the stage of grammaticalization that they would later attain, were able to express semantic properties similar to those expressed by inflectional mood, while additionally making finer distinctions regarding the relations between the situation described and the actual world. In a translated text such as Bede, it is possible to distinguish between modal verbs translating a similar Latin verb and modal verbs interpolated by the translator. Instances of the latter sort may be especially relevant to the questions that we are investigating; if the translator felt it advisable to use a modal verb in a sentence that originally made no explicit reference to concepts such as necessity, possibility, volition, etc., this may indicate some of the communicative limitations of the Old English inflectional system.

\begin{tabular}{|l|c|}
\hline & Added modals \\
\hline Causal & $2.52 \%(3 / 119)$ \\
\hline Complement & $6.64 \%(17 / 256)$ \\
\hline Concessive & $1.82 \%(1 / 55)$ \\
\hline Conditional & $16.1 \%(20 / 124)$ \\
\hline Purpose & $25.6 \%(11 / 43)$ \\
\hline Result & $2.50 \%(1 / 40)$ \\
\hline Temporal & $2.66 \%(14 / 527)$ \\
\hline Total & $6.12 \%(64 / 1045)$ \\
\hline
\end{tabular}

Table 5: Added modals

It can be seen from Table 5 that the interpolation of modal verbs is much more common in constructions of some types than in others. The highest percentage is seen in purpose clauses. As shown in Section 4.3 above, mood is often the sole formal cue distinguishing purpose clauses from result clauses; it may therefore be that the greater frequency of modals in such environments reflects a desire for a morphologically unambiguous means of indicating world reference. There is in fact some association 
between modal use and constructions that would have been morphologically ambiguous in non-modal form, as can be seen in the following table:

\begin{tabular}{|l|c|c|}
\hline & Added modal & No added modal \\
\hline Unambiguous & $3.2 \%(22 / 695)$ & $96.8 \%(673 / 695)$ \\
\hline Ambiguous & $9.3 \%(45 / 485)$ & $90.7 \%(440 / 485)$ \\
\hline Total & $5.7 \%(67 / 1180)$ & $94.3 \%(1113 / 1180)$ \\
\hline
\end{tabular}

Table 6: Modals and morphological ambiguity ${ }^{21}$

This association is statistically significant $\left(\chi^{2}(1)=19.931, p<0.01\right)$. However, other factors must also be at work; modals are often added even when there would have been no such ambiguity to avoid.

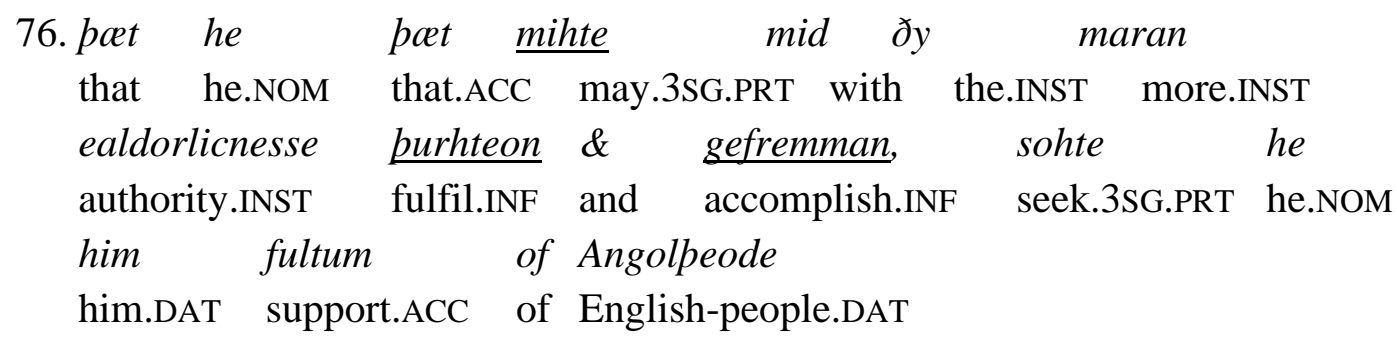

'So that he might fulfil and accomplish this with greater authority, he sought help for himself from the English people.' (V 19.468.8)

In this example, mihte 'might' has been added by the translator; the Latin text has only an imperfect subjunctive, perficeret. In the corresponding English verb, though, there would have been no morphological ambiguity in the third person singular of the preterite; the indicative purhteah and subjunctive purhtuge would have provided little opportunity for conflation.

Another factor favouring the use of modals is clarification of temporal reference. There are some contexts where modal and non-modal counterparts might receive different temporal interpretations, such as the following:

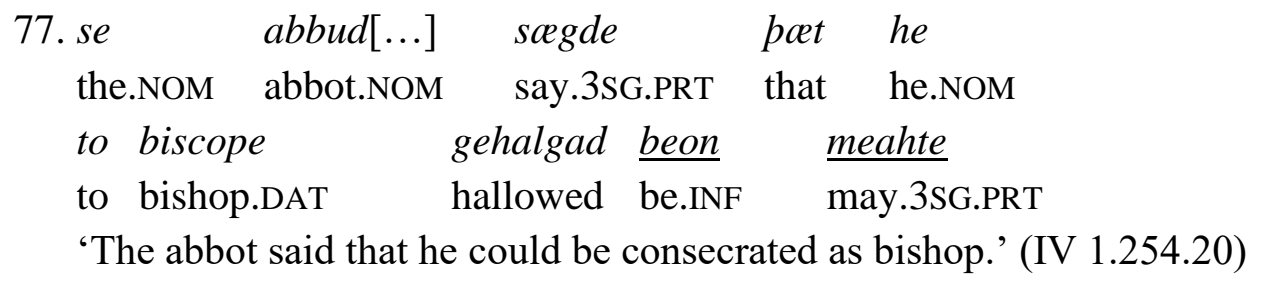

In this case the addition of meahte makes it clear that the speaker was referring to a future possibility. The use of the subjunctive after secgan 'say' was common enough, even in factual contexts, that world reference could not be signalled unambiguously through the choice of mood alone; a simple subjunctive ware could thus have been

${ }^{21}$ Cases that have proved difficult to classify definitively have been excluded from these totals. 
seen as denoting simultaneity ('was being consecrated') or anteriority ('had been consecrated'). In Latin the greater number of tense and aspect distinctions could often reduce the potential for such ambiguity even without recourse to modal forms; during the translation of a Latin text into Old English, though, the restrictions of the Old English verbal system might tend to favour the introduction of new modals into the text.

From a diachronic perspective, the interpolation of modals into the translation of Bede can be seen as part of a broader trend, away from a reliance on inflectional mood as the primary means of expressing semantic concepts such as world reference and towards the use of specialized modal lexemes. It is possible to identify some of the factors involved in this process, such as the growing syncretism and resulting ambiguity of Old English mood morphology and the ability of modals to mark temporal as well as modal properties more explicitly. However, there are also examples, such as (76) above, which are less easy to relate to functional factors; in some cases, the choice between bare subjunctives and modal constructions may simply reflect the choice of individual speakers among roughly equivalent ways of expressing the same meaning.

\subsection{MOOD IN LATIN AND OLD ENGLISH SUBORDINATE CLAUSES}

At this point it may be useful to recapitulate some of the differences between the mood system of Old English and that of Latin (on which see Appendix 2).

Complement clauses present a much more varied picture in Old English than in Latin, with Old English making more extensive use of the indicative. Unlike Latin, both the indicative and the subjunctive could be used in indirect questions and assertions, as well as in existential constructions used to assert the existence of events within a narrative. This greater flexibility means that mood selection in complement clauses was available to Old English speakers as a potential means of drawing semantic distinctions, although the extent to which they made use of this potential remains in some respects unclear. Old English also differs from Latin in using the indicative for result clauses, as distinct from purpose clauses; in these environments inflectional mood could still be used as the primary indicator of a salient semantic distinction. Conversely, in Old English the mood of concessive clauses has become fixed as subjunctive, while Latin still permitted a greater degree of variation. Old English and Latin remain broadly similar in their use of mood in conditionals and in temporal clauses, although in the latter case the use of the subjunctive with cum has no parallel in Old English. 


\begin{tabular}{|l|r|c|c|c|c|}
\cline { 3 - 6 } \multicolumn{2}{c|}{} & \multicolumn{2}{c|}{ Latin } & \multicolumn{2}{c|}{ Old English } \\
\cline { 3 - 6 } \multicolumn{2}{c|}{} & Indicative & Subjunctive & Indicative & Subjunctive \\
\cline { 2 - 6 } \multirow{3}{*}{ Temporal } & $\mathrm{w}$ & $16.3 \%(50)$ & $83.7 \%(257)$ & $96.3 \%(158)$ & $3.7 \%(6)$ \\
\cline { 2 - 6 } & $\neq \mathrm{w}$ & $25.0 \%(1)$ & $75.0 \%(3)$ & $0 \%(0)$ & $100 \%(4)$ \\
\hline \multirow{2}{*}{ Result } & $\mathrm{w}$ & $0 \%(0)$ & $100 \%(1)$ & - & - \\
\hline Purpose & $\exists \mathrm{w}$ & $0 \%(0)$ & $100 \%(43)$ & $0 \%(0)$ & $100 \%(25)$ \\
\hline Causal & $\mathrm{w}$ & $80.6 \%(58)$ & $19.4 \%(14)$ & $100 \%(39)$ & $0 \%(0)$ \\
\hline \multirow{3}{*}{ Concessive } & $\mathrm{w}$ & $50.0 \%(10)$ & $50.0 \%(10)$ & $0 \%(0)$ & $100 \%(13)$ \\
\cline { 2 - 6 } & $\exists \mathrm{w}$ & $0 \%(0)$ & $100 \%(1)$ & - & - \\
\hline \multirow{3}{*}{ Complement } & $\mathrm{w}$ & $39.3 \%(22)$ & $60.7 \%(34)$ & $100 \%(36)$ & $0 \%(0)$ \\
\cline { 2 - 6 } & $\exists \mathrm{w}$ & $9.9 \%(19)$ & $90.1 \%(172)$ & $17.6 \%(18)$ & $82.4 \%(84)$ \\
\cline { 2 - 6 } & $\neq \mathrm{w}$ & - & - & - & - \\
\hline \multirow{3}{*}{ Conditional } & $\mathrm{w}$ & $71.4 \%(25)$ & $28.6 \%(10)$ & $100 \%(28)$ & $0 \%(0)$ \\
\cline { 2 - 6 } & $\exists \mathrm{w}$ & $31.3 \%(10)$ & $68.8 \%(22)$ & $0 \%(0)$ & $100 \%(24)$ \\
\cline { 2 - 6 } & $\neq \mathrm{w}$ & $0 \%(0)$ & $100 \%(3)$ & $0 \%(0)$ & $100 \%(2)$ \\
\hline
\end{tabular}

Table 7: Mood in subordinate clauses in the Latin and Old English versions of Bede

This table provides a comparison of mood in the Latin and Old English Bede. It includes only examples where the clause type is the same in both languages, and excludes combinations of different clause types where the choice of mood may reflect a conflation of multiple factors (e.g. other clauses embedded in indirect discourse); morphologically ambiguous forms have been omitted for clarity. In general, there are obvious similarities in the use of mood between the two languages. However, in different areas each language shows some rigidity in the use of mood, so that a given mood may be used almost exclusively in a certain construction without reference to contextual parameters such as world reference. Despite this growing rigidity, there remain environments such as conditionals or Old English paet-clauses, in which mood is not only variable but provides one of the primary cues to resolve potential ambiguities.

\section{SUMMARY AND CONCLUSION}

There is a strong correlation between grammatical mood and semantic category in the OE Bede. As we saw in Section 4.1, the subjunctive in main clauses always correlates with the semantic category ' $\exists w$ '; and, as the table in Section 4.9 shows, the indicative is used predominantly or exclusively when the semantic category is ' $\mathrm{w}$ ' and the subjunctive when the semantic category is ' $\exists \mathrm{w}$ ', or ' $\neq \mathrm{w}$ '. Moreover, grammatical mood is used to disambiguate result clauses and purpose clauses, two types introduced by paet which might otherwise be confused. In a few other types of clause, e.g. in complement clauses after verbs of speaking, there is variation between the moods, although it is not certain what the functional difference between them is, if any. 
However, the correlation between grammatical mood and semantic category is not perfect. In temporal clauses introduced by conjunctions meaning 'before' and 'until' and in all concessive clauses, the subjunctive is systematically used regardless of the semantic category; see Sections 4.2 and 4.5, respectively. Moreover, even when grammatical mood and semantic category correlate, that does not in itself mean that the former determines the latter. This is because there are often contextual cues which point to the semantic category of the clause apart from grammatical mood. In complement clauses, most matrix verbs require a particular semantic category, and the grammatical mood merely follows this requirement; thus verbs meaning 'to know' demand a complement clause representing a ' $\mathrm{w}$ ' situation and introduce clauses with the indicative, while verbs meaning 'to bid, ask, entreat' demand a complement clause representing a ' $\exists \mathrm{w}$ ', or ' $\neq \mathrm{w}$ ' situation and are followed by the subjunctive. In conditional clauses, the present indicative is generally used for ' $w$ ' situations and the past subjunctive tense for ' $\exists \mathrm{w}$ ' or ' $\neq \mathrm{w}$ ' situations, so that both the choice of tense and the choice of mood provides a cue to the semantic category.

So although there is a high correlation between grammatical mood and semantic category, the semantic category is signalled by other means as well, and the choice of mood is consistent with that signal rather than making an incremental semantic contribution. The principal incremental contribution of grammatical mood in subordinate clauses in the $\mathrm{OE}$ Bede is in disambiguating result and purpose clauses. Given the large number of ambiguous verb forms in the OE Bede, even grammatical mood is not always available to achieve this, and it is significant that the highest incidence of interpolated modal verbs, which are an unambiguous alternative to the subjunctive, occurs in purpose clauses.

These properties suggest a system of mood intermediate between those depicted for Latin and French in Section 1. The correlation between grammatical mood and semantic category is sufficiently strong to be learnable, and speakers are able to make use of the recognizable semantic properties of the moods in environments where choice existed, such as main clauses. However, given that grammatical mood in subordinate clauses was largely predictable from clause type or other cues, and that in its disambiguating function the subjunctive was replaceable by modal verbs, we conclude that this mood was close to being semantically redundant in subordinate clauses in the $\mathrm{OE} \mathrm{Bede.} \mathrm{In} \mathrm{addition,} \mathrm{there} \mathrm{were} \mathrm{a} \mathrm{growing} \mathrm{number} \mathrm{of} \mathrm{environments} \mathrm{in}$ which grammatical mood was not fully predictable on semantic grounds; although the mood may still have been interpretable in semantic terms for speakers, there would have been a need to learn the behaviour of different constructions individually. Even in the absence of external factors, it might seem reasonable to suppose that the continued operation of these trends could have led to a reduced role for morphological mood. Further research on other languages may clarify the extent to which the properties observed in Old English are paralleled in other languages at a similar stage of development. 


\section{Appendix 1 - Details of the semantic model}

We set out in Table 8 a more formal model of each of the clause types mentioned in Section 2. The purpose is to provide more details of the different modalities of these clause types. In the first column we repeat the examples used in Section 2. A more formal analysis is given in the second column: in the case of subordinate clauses, this analysis includes both the subordinate clause and the main clause on which it depends. In the third column we enter ' $w$ ' if the proposition in the clause in question is represented as obtaining in the actual world (of the speaker); ' $\exists \mathrm{w}$ ' if the proposition is represented as obtaining in some possible world, which may be the actual world; and ' $\neq \mathrm{w}$ ' if the proposition is represented as obtaining in a possible world other than the actual world. The final column includes explanations of the formal analysis and a key defines the notation used.

For the sake of brevity we do not show examples of every tense in which each clause type occurs. In most cases we give examples with past time reference, reflecting the narrative perspective of much of the OE Bede, but the semantic analysis given applies to examples with other time references, e.g. present or future. However, in the empirical analysis we pay attention to the interaction between modality and time reference when this is important to the analysis.

The more formal account given here draws on previous possible-world accounts of modality. However, since those accounts tend to focus on one or a small number of clause types, we have created our own notation which is intended to model on a consistent basis all the clause types which we analyse in the OE Bede. The references which have proved most useful in drawing up this model are von Fintel (2012) on conditional clauses, Goranko and Galton (2015) on temporal clauses, König and Siemund (2000) on causal and concessive clauses, Portner (2018) on complement clauses, and Menzel (2017) on possible world semantics in general. It should be noted that the more formal account in Table 8 is not intended as a logical calculus of modality, but merely to show where the differences in modality lie in the clause types found in the $\mathrm{OE}$ Bede. 


\section{Table 8}

\begin{tabular}{|c|c|c|c|}
\hline Examples from Section 2 & $\begin{array}{l}\text { More formal analysis of } \\
\text { clause types }^{22}\end{array}$ & World & Comments \\
\hline \multicolumn{4}{|l|}{ Main clauses } \\
\hline 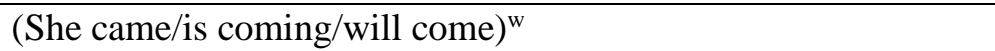 & $a^{w}$ & $\mathrm{~W}$ & \multirow{2}{*}{$\begin{array}{l}\text { Almost all main clauses in our data set are } \\
\text { declarative. }\end{array}$} \\
\hline 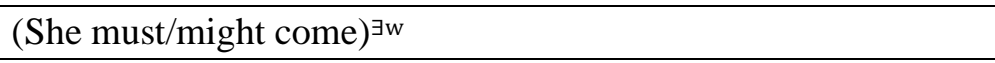 & $\mathrm{a}^{\exists \mathrm{w}}$ & $\exists \mathrm{w}$ & \\
\hline \multicolumn{4}{|l|}{ Temporal } \\
\hline He came home (before she started worrying) ${ }^{\mathrm{w}}$ & $\mathrm{a}^{\mathrm{w}}<\mathrm{b}^{\mathrm{w}}$ & $\mathrm{W}$ & \multirow{6}{*}{$\begin{array}{l}\text { Under the ' } \exists w \text { ' and ' } \neq w \text { ' interpretations of } \\
\text { 'before' and 'until', b obtains in a possible } \\
\text { world, as opposed to the actual world of } \\
\text { the speaker. }\end{array}$} \\
\hline He came home (before she started worrying) ${ }^{\neq w}$ & $\mathrm{a}^{\mathrm{w}}<\mathrm{b}^{\neq \mathrm{w}}$ & $\neq \mathrm{W}$ & \\
\hline She was waiting (until he came) ${ }^{\mathrm{w}}$ & $a^{\mathrm{w}} \leq \mathrm{b}^{\mathrm{w}}$ & $\mathrm{w}$ & \\
\hline She was waiting (until he came) ${ }^{\exists w}$ & $\mathrm{a}^{\mathrm{w}} \leq \mathrm{b}^{\exists \mathrm{w}}$ & $\exists \mathrm{w}$ & \\
\hline She felt ill (after she ate ice-cream) ${ }^{\mathrm{w}}$ & $\mathrm{a}^{\mathrm{w}}>\mathrm{b}^{\mathrm{w}}$ & $\mathrm{W}$ & \\
\hline She was happy (when/while she was with him) ${ }^{\mathrm{w}}$ & $\mathrm{a}^{\mathrm{w}} \sqsubseteq \mathrm{b}^{\mathrm{w}}$ & W & \\
\hline \multicolumn{4}{|l|}{ Causal } \\
\hline The baby woke up (because Mary made a noise) ${ }^{\mathrm{w}}$ & $\mathrm{a}^{\mathrm{w}} \&(\neg \mathrm{a} \rightarrow \neg \mathrm{b})^{\mathrm{w}} \&(\mathrm{a} \rightarrow \mathrm{b})^{\mathrm{w}}$ & $\mathrm{W}$ & $\begin{array}{l}\text { These are modelled as follows: a obtains } \& \\
\text { if there is no a, there is no } b \& \text { if there is a, } \\
\text { there is b. The analysis is the same as for } \\
\text { result clauses. }\end{array}$ \\
\hline \multicolumn{4}{|l|}{ Result } \\
\hline Mary made a noise (so that the baby woke up) ${ }^{\mathrm{w}}$ & $\mathrm{a}^{\mathrm{w}} \&(\neg \mathrm{a} \rightarrow \neg \mathrm{b})^{\mathrm{w}} \&(\mathrm{a} \rightarrow \mathrm{b})^{\mathrm{w}}$ & $\mathrm{W}$ & $\begin{array}{l}\text { These are modelled as follows: a obtains } \& \\
\text { if there is no a, there is no b \& if there is a, } \\
\text { there is b. The analysis is the same as for } \\
\text { causal clauses. }\end{array}$ \\
\hline \multicolumn{4}{|l|}{ Purpose } \\
\hline Mary made a noise (so that the baby woke up/might wake up) ${ }^{\exists w}$ & $\mathrm{a}^{\mathrm{w}} \&(\neg \mathrm{a} \rightarrow \neg \mathrm{b})^{\mathrm{w}} \&(\mathrm{a} \rightarrow \mathrm{b})^{\exists \mathrm{w}}$ & $\exists \mathrm{w}$ & \multirow{2}{*}{$\begin{array}{l}\text { These are modelled like result clauses, but } \\
\text { the last part }(\mathrm{a} \rightarrow \mathrm{b}) \text { is in a possible world. }\end{array}$} \\
\hline & & & \\
\hline
\end{tabular}

${ }^{22}$ Where subordinate clauses are formalized, the main clause on which they depend is included in the formalization. 


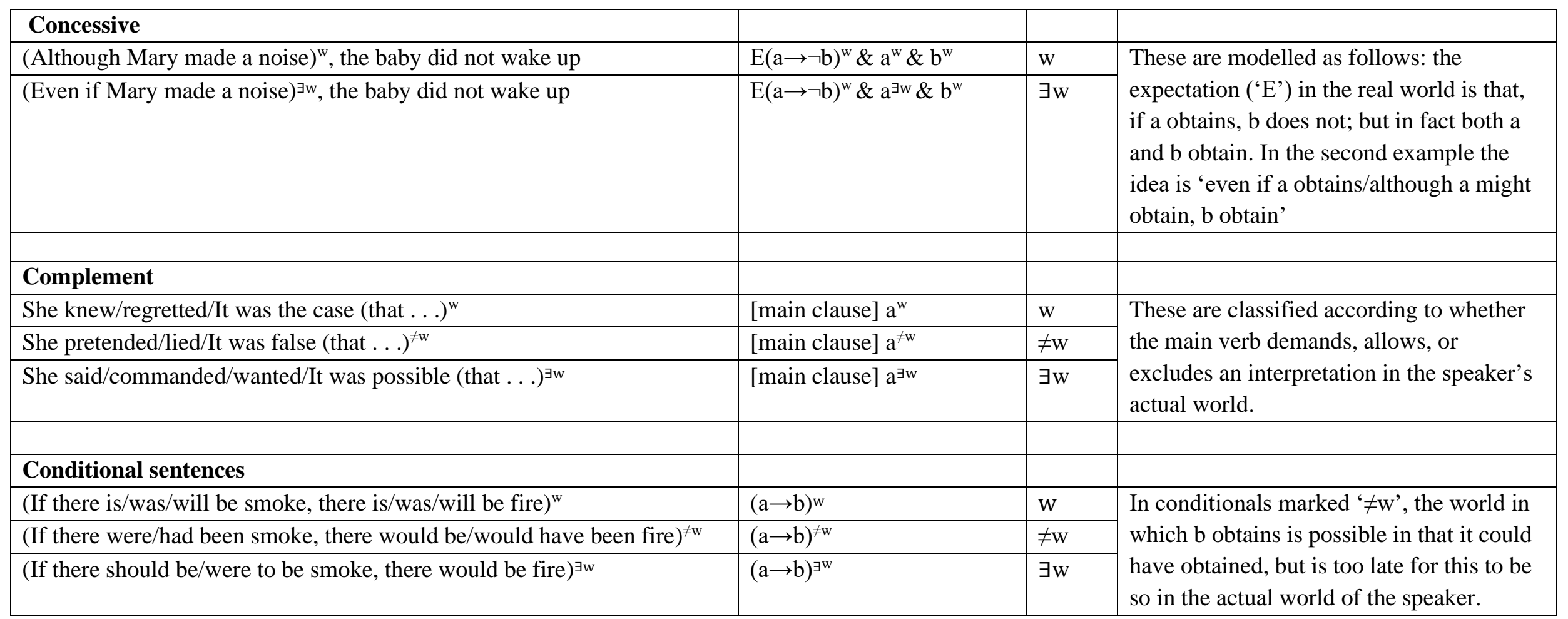

\begin{tabular}{|l|l|}
\hline Symbol & Definition \\
\hline & \\
\hline $\mathrm{a}, \mathrm{b}$ & propositions \\
\hline $\mathrm{a} \rightarrow \mathrm{b}$ & if $\mathrm{a}$, then $\mathrm{b}^{23}$ \\
\hline$\&$ & and \\
\hline $\mathrm{Ea}$ & it is expected that a \\
\hline$\neg \mathrm{a}$ & not a \\
\hline$\leq$ & until \\
\hline$<$ & before \\
\hline
\end{tabular}

${ }^{23}$ The symbol ' $\rightarrow$ ' here stands for 'strict implication' along the lines described by von Fintel (2012). Strict implication allows us to avoid the problem which arises with material implication when the condition in the protasis is highly improbable. For example, in "If that's Barack Obama, then I'm the Queen of Sheba", material implication allows "I'm the Queen of Sheba" to be true even if that isn't Barack Obama. 


\begin{tabular}{|l|l|}
\hline$>$ & after \\
\hline$\subseteq$ & when/while \\
\hline $\mathrm{w}$ & in the actual world \\
\hline$\neq \mathrm{w}$ & in some possible world but not in the actual world \\
\hline$\exists \mathrm{w}$ & in some possible world \\
\hline
\end{tabular}




\section{Appendix 2 - Details of the relationship between mood and modality in the Latin Bede}

We set out in Table 9 the Latin clauses arranged by the same broad types (with subtypes in some cases) as those in which we organize the empirical analysis of Old English in Section $4 .{ }^{24}$ For subordinate clauses we note down the conjunction or conjunctions introducing each (sub)type. In the 'world' column we indicate which of the modal categories (' $w$ ', ' $\exists w$ ', or ' $\neq w$ ') from Appendix 1 applies to each clause (sub)type.

It is clear from Table 9 that, among the clause types analysed, the Latin indicative is used only to represent the actual world of the narrator (i.e. 'w'), but that the relationship between the subjunctive and the 'world' category is far from consistent: as we explain in Section 2, in some clause (sub)types, e.g. purpose clauses, the subjunctive is used consistently to represent a ' $\exists w$ ' or ' $\neq w$ ' world; in others, e.g. result clauses, the subjunctive is used consistently to represent a ' $w$ ' world; and in others still, e.g. concessive and temporal clauses, the subjunctive can be used to represent actual and possible worlds. The choice of the subjunctive therefore appears to be a complex function of clause type, modality, and conjunction.

For an analysis of the grammar of main and subordinate clauses in Bede's Historia Ecclesiastica, including comments on the choice of mood and a comparison with Classical usage, see Druhan (1938). For a recent attempt to define a unified semantic function for the Classical Latin subjunctive, together with a review of the literature, see Müller-Wetzel (2001). Müller-Wetzel argues that the function of the subjunctive in main clauses is equivalent to that of modal verbs, except that the subjunctive leaves the exact modal category (volition, obligation, etc) unspecified. In subordinate clauses, Müller-Wetzel maintains that, by using the subjunctive, the speaker denies responsibility for the proposition contained in that clause (as opposed to denying the truth of the proposition). The notion that the indicative and subjunctive signal $+/-$ speaker responsibility, respectively, can be likened to the possible worlds model used in the present paper, where the indicative signals the actual world of the speaker and the subjunctive signals only a possible world. The two models would be equivalent (for subordinate clauses) if we defined 'proposition representing a situation in the actual/a possible world' (our model) with 'proposition for which the speaker does/does not take responsibility' (Müller-Wetzel). However, even if we assume this equivalence for the sake of argument, it is clear that our analysis of the Latin subjunctive is fundamentally different from that of Müller-Wetzel, in that we find a number of (sub)clause types in which the subjunctive is used to denote situations which are represented as being in the actual world of the speaker.

\footnotetext{
${ }^{24}$ The data underlying the table exclude subordinate clauses embedded within each other, since, in such cases, the mood of the inner clause may be a function of the mood, type, or modality of the outer clause type.
} 
Table 9

\begin{tabular}{|c|c|c|c|c|}
\hline Clause type & Clause subtype & Conjunction & Mood & World \\
\hline Main clause & - & $\mathrm{n} / \mathrm{a}$ & $\operatorname{subj}^{25}$ & $\exists w$ \\
\hline \multicolumn{5}{|l|}{ Temporal } \\
\hline & 'before' & antequam/priusquam & subj & $\mathrm{w}$ and $\neq \mathrm{w}$ \\
\hline & 'until' & donec & indic & $\mathrm{w}$ \\
\hline & 'until' & donec & subj & $\mathrm{w}$ and $\exists \mathrm{w}$ \\
\hline & 'until' & quousque/quoadusque & indic & $\mathrm{w}$ \\
\hline & 'until' & usquedum & indic & $\mathrm{w}$ \\
\hline & 'until' & usquedum & subj & $\mathrm{w}$ \\
\hline & 'after' & postquam & indic & $\mathrm{w}$ \\
\hline & 'when' & cum & indic & $\mathrm{w}$ \\
\hline & 'when' & cum & subj & $\mathrm{w}$ \\
\hline & 'when' & quando & indic & $\mathrm{w}$ \\
\hline & 'when' & $u b i$ & indic & $\mathrm{w}$ \\
\hline & 'when' & $u t$ & indic & $\mathrm{w}$ \\
\hline & 'when/while' & dum & indic & $\mathrm{w}$ \\
\hline & 'when/while' & $d u m$ & subj & $\mathrm{w}$ \\
\hline & 'when/while' & quamdiu & indic & $\mathrm{w}$ \\
\hline \multirow[t]{5}{*}{ Causal $^{26}$} & - & quod & indic & $\mathrm{w}$ \\
\hline & & quod & subj & $\mathrm{w}$ and $\exists w$ \\
\hline & & quia & indic & $\mathrm{w}$ \\
\hline & & quoniam & indic & $\mathrm{w}$ \\
\hline & & utpote qui etc. & indic & $\mathrm{w}$ \\
\hline Result & - & $u t$ & subj & $\mathrm{w}$ \\
\hline Purpose & - & ut/ne & subj & $\exists w$ \\
\hline \multirow[t]{5}{*}{ Concessive } & & cum & subj & $\mathrm{w}$ \\
\hline & & etiamsi & subj & $\mathrm{w}$ \\
\hline & & etsi, tametsi & indic & $\mathrm{w}$ \\
\hline & & quamvis & indic & $\mathrm{w}$ \\
\hline & & quamvis & subj & $\mathrm{w}$ and $\exists \mathrm{w}$ \\
\hline \multicolumn{5}{|l|}{ Complement } \\
\hline & command/petition/prohibition & ut/ne & subj & $\exists w$ \\
\hline & fearing & ne & subj & $\exists w$ \\
\hline & doubting & quin & subj & $\exists w$ \\
\hline & indirect question & [any question word] & subj & $\exists w$ \\
\hline & indirect statement (e.g. dixit quod...) & quod/quia/ut & subj & $\exists w$ \\
\hline & indirect assertion (e.g. scivit quia...) & quia & indic & $\mathrm{w}$ \\
\hline
\end{tabular}

\footnotetext{
${ }^{25}$ Our analysis of main clauses excludes those with a verb in the indicative (see Section 4.1).

${ }^{26}$ Many Latin causal clauses in Bede are main clauses with the verb in the indicative, introduced by nam or enim (in first and second position in their clauses, respectively).
} 
narrative assertion (e.g. factum est quod/contigit ut...)

Conditional

actual world

possible world quod/ut

subj

W si/nisi

si/nisi indic

subj $\quad \exists w$ and $\neq w$ 


\section{TEXTUAL SOURCES}

PlumMER, CHARLES (ed.) 1896. Venerabilis Baedae historiam ecclesiasticam gentis Anglorum. Oxford: Clarendon. http://www.perseus.tufts.edu/hopper/text?doc=Perseus\%3atext\%3a1999.02.0135 (28 September, 2019.)

TAYLOR, ANN, ANTHONY WARNER, SUSAN PINTZUK \& FRANK BETHS (eds.) 2003. The York-TorontoHelsinki parsed corpus of Old English prose. York: University of York, electronic.

\section{REFERENCES}

Allen, J. H., J. B. Greenough, G. L. Kittredge, A. A. Howard AND B. L. D’Ooge (eds.) 1903. Allen and Greenough's new Latin grammar for schools and colleges, rev. edn. Boston: Ginn.

Austin, J. L. 1961. 'Ifs and cans', in J. L. Austin (ed.) Philosophical papers, Oxford: Oxford University Press, 153-180.

BEHRE, FRANK. 1934. The subjunctive in Old English poetry. Göteborg: Elanders.

ClACKSON, JAMES AND HORROCKS, GEOFFREY C. 2007. The Blackwell history of the Latin language. Malden, MA: Blackwell.

DRUHAN, D.R. 1938. The syntax of Bede's 'Historia Ecclesiastica'. Catholic University Studies in Medieval and Renaissance Latin, vol. 8. Washington, DC: Catholic University.

EDGington, DoROTHY. 2014. 'Indicative Conditionals', in Edward N. Zalta (ed.), The Stanford encyclopedia of philosophy, Winter $2014 \mathrm{ed}$. https://plato.stanford.edu/entries/conditionals/ (28 September, 2019.)

VON FINTEL, KAI. 2012. 'Conditionals', in Claudia Maienborn, Klaus Heusinger, and Paul Portner (eds.), Semantics: An international handbook of natural language meaning, vol. 2, Berlin: De Gruyter, 1515-37.

FISCHER, Olga. 1992. 'Syntax', in Norman Blake (ed.), The Cambridge history of the English language, vol. 2, Cambridge: Cambridge University Press, 207-408.

GOODWIN, WILLIAM WATSON. 1889. Syntax of the moods and tenses of the Greek verb, rev. edn. London: Macmillan.

Goranko, Valentin \& Galton, Antony. 2015. 'Temporal Logic', in Edward N. Zalta (ed.), The Stanford encyclopedia of philosophy, Winter $2015 \mathrm{ed}$. https://plato.stanford.edu/archives/win2015/entries/logictemporal/ (28 September, 2019.)

GORRELL, J. HENDREN. 1895. 'Indirect discourse in Anglo-Saxon', PMLA 10 (3), 342-485.

HOGG, RICHARD. 1988. 'On the impossibility of Old English dialectology', in Dieter Kasatovsky and Gero Bauer (eds.) Luick Revisited, Tübingen: Narr, 183-203.

HogG, RICHARD. 1992. 'Phonology and morphology', in Richard Hogg (ed.) The Cambridge history of the English language, vol. 1, Cambridge: Cambridge University Press, 67-167.

IATRIDOU, SABINE. 2000 ‘The grammatical ingredients of counterfactuality’, Linguistic Inquiry 31, 237-270.

KÖNIG, EKKEHARD AND PETER SIEMUND. 2000. 'Causal and concessive clauses: Formal and semantic relations', in Elizabeth Couper-Kuhlen and Bernd Kortmann (eds.) Cause - Condition - Concession Contrast: Cognitive and Discourse Perspectives, Berlin: Mouton de Gruyter, 341-360.

LEWIS, DAVID. 1973. 'Causation', Journal of Philosophy 70 (17), 556-67. 
MEnZel, Christopher. 2017. 'Possible Worlds', in Edward N. Zalta (ed.), The Stanford encyclopedia of philosophy, Winter 2017 ed. https://plato.stanford.edu/archives/win2017/entries/possible-worlds/ (28 September, 2019.)

Miller, Thomas. (ed.) 1890. The Old English Version of Bede's 'Ecclesiastical History of the English People'. Early English Text Society, 95-6. London: Trübner.

MÜLler-Wetzel, M. 2001. Der lateinische Konjunktiv: Seine Einheit als deiktische Kategorie; eine Erklarung der modalen Systeme der klassischen Zeit. Hildesheim/Zürich/New York: Olms-Weidmann.

MitCHELL, BRUCE. 1984. 'The origin of Old English conjunctions: Some problems', in Jacek Fisiak (ed.), Historical Syntax, Berlin: Mouton, 271-299.

MitCheLL, BRUCE. 1985. Old English Syntax, 2 vols. Oxford: Clarendon Press.

Mithun, MARIANNE. 1999. The languages of Native North America. Cambridge: Cambridge University Press.

NORDSTRÖM, JACKIE. 2010. Modality and Subordinators. Amsterdam: Benjamins.

Palmer, F. R. 2001. Mood and Modality, 2nd ed. Cambridge: Cambridge University Press.

PORTNER, PAUL. 1997. 'The semantics of mood, complementation, and conversational force', Natural Language Semantics 5, 167-212.

PORTNER, PAUL. 2018. Mood. Oxford: Oxford University Press.

RANDAll, Beth. 2010. CorpusSearch. Version 2.002.74. Philadelphia: University of Pennsylvania, electronic.

RINGe, Don \& ANn TAYLOR. 2014. The Development of Old English. Oxford: Oxford University Press.

STALNAKER, ROBERT. 2014. Context. Oxford: Oxford University Press.

Trost, PAUl. 1939. 'Zum lateinischen Kondizionalsatz', Glotta 27, 206-11.

Whitelock, DoRothy. 1962. 'The Old English Bede', Proceedings of the British Academy 48, 57-90.

WiLlmott, Jo. 2007. The Moods of Homeric Greek. Cambridge: Cambridge University Press. 